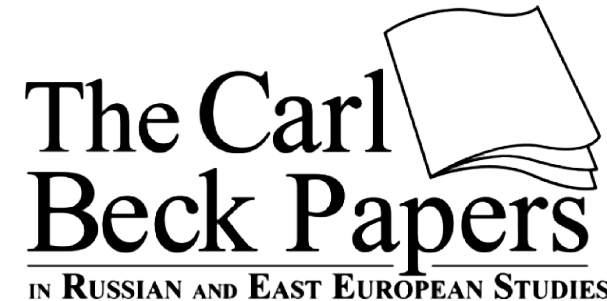

Number 2401
Victor Taki

\section{Limits of Protection:}

Russia and the Orthodox Coreligionists in the Ottoman Empire

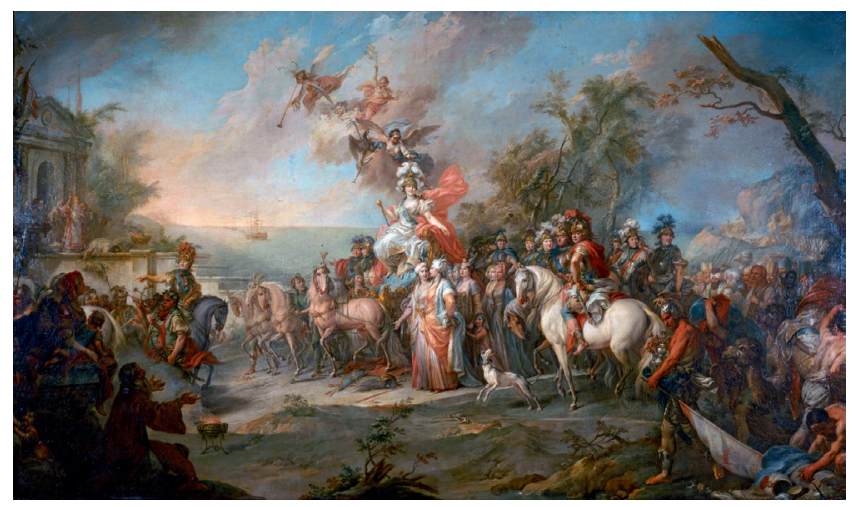




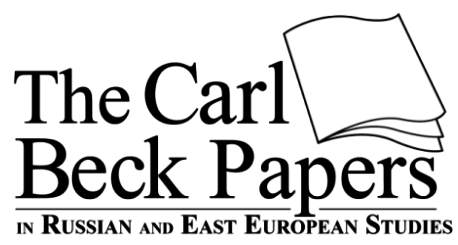

Number 2401

ISSN: 0889-275X (print)

\section{Victor Taki}

\section{Limits of Protection:}

Russia and the Orthodox Coreligionists in the Ottoman Empire

(cc) BY-No-ND This work is licensed under a Creative Commons
Attribution-Noncommercial-No Derivative Works

3.0 United States License.

This site is published by the University Library System of the University of Pittsburgh as part of its D-Scribe Digital Publishing Program, and is cosponsored by the University of Pittsburgh Press. 
Victor Taki holds MA and Ph.D. degrees from Central European University (Budapest, Hungary). His doctoral dissertation, "Russia on the Danube: Imperial Expansion and Political Reform in Moldavia and Wallachia, 1812-1834" examined discursive and institutional aspects of the relations between the Russian Empire and the elites of the two Romanian principalities at the dawn of the modern epoch. His most recent publications are "Orientalism at the Margins: The Ottoman Empire under Russian Eyes," Kritika, no. 2 (2011), 321-351, and a co-authored monograph "Bessarabia as Part of the Russian Empire, 1812-1917" (Moscow: Novoie Literaturnoie Obozrenie, 2012) (in Russian).

No. 2401, April 2015

2015 by The Center for Russian and East European Studies, a program of the University Center for International Studies, University of Pittsburgh

ISSN 0889-275X (print) ISSN 2163-839X (online)

Image from cover:

Stefano Torelli, Allegory of Catherine's Victory over the Turks (1772)

Public domain

\section{The Carl Beck Papers}

Publisher: University Library System, University of Pittsburgh

Editors: William Chase, Bob Donnorummo, Andrew Konitzer, Robert Hayden

Managing Editor: Matt Clews

Editor Emeritus: Ronald H. Linden

Submissions to The Carl Beck Papers are welcome. Manuscripts must be in English, doublespaced throughout, and between 40 and 90 pages in length, including notes. Acceptance is based on anonymous review. Manuscripts can be submitted on The Carl Beck Papers website, http://carlbeckpapers.pitt.edu. Please direct all inquiries to Matthew Clews, Managing Editor, at carlbeckpapers@mail.pitt.edu. 
Influence over the Ottoman Christians was the single most important manifestation of Imperial Russia's "soft power." In the context of the Russian-Ottoman wars of the eighteenth and early nineteenth century, appeals of the Eastern Christian elites to Moscow and St. Petersburg for protection met with the attempts of the tsars and their commanders to rally the support of the co-religionists. However, Russia's relations with the Orthodox subjects of the sultan were fraught with great ambiguity. Temporary Russian occupations of particular territories of Turkey-in-Europe during the wars incited among the local Christians the hopes for independence that subsequent restoration of the Porte's authority would all but destroy. In order to maintain Russia's standing among the co-religionists, the peace treaty of KuchukKainarji of 1774 and subsequent Russian-Ottoman agreements included certain guarantees in favor of the Christian population of the returned territories. The present paper offers a comparative perspective on these arrangements, which served the basis for trilateral relations between Russia, the Porte and the elites of Moldavia, Wallachia, the Archipelago and Serbia in the late 1700s and early 1800s. The difference in attitudes and behaviour of the Romanian, Greek and Serbian leaders arguably explains varying degrees of autonomy that the territories in question enjoyed on the basis of the Russian-Ottoman treaty stipulations. More broadly, the paper seeks to problematize the notion of Russia's protectorate over the Orthodox co-religionists. It shows that the legal basis of this protectorate remained very uneven, and, that for a long time, the makers of Russia's Eastern policy dealt with particular Christian elites of Turkeyin-Europe rather than with the entire Orthodox community of the Ottoman Empire.
\end{abstract}




\section{Limits of Protection: Russia and the Orthodox Coreligionists in the Ottoman Empire}

On January 19, 1769, soon after the outbreak of the first "Turkish war" of her reign, Catherine II addressed a manifesto to "the Greek and Slavic peoples of the Orthodox religion" in the Ottoman Empire. In it, the Russian empress spoke of their "sorry state" under the "Ottoman yoke" and announced her intention "to aid their liberation and relief inasmuch as possible." The manifesto called Russia's coreligionists to "take advantage of the circumstances of this war in order to destroy the yoke and return to their erstwhile state of independence by taking arms wherever possible against the common enemy of the entire Christendom." In this way, assured the empress, the Ottoman Christians would "contribute to [the improvement of] their own lot, which will receive a sacred and inviolable guarantee in the future peace with the Ottoman Empire."1

In her manifesto to the Ottoman Christians, Catherine II built upon the legacy of Peter the Great, the first Russian ruler who seriously attempted to raise the Orthodox coreligionists for an anti-Ottoman struggle. The fateful Pruth Campaign of 1711 was the first Russian-Ottoman war in what was then known as Turkey-in-Europe, the outbreak of which owed much to the efforts of the Swedish king Charles XII, resident of the Ottoman fortress Bender since his defeat at Poltava in 1709. ${ }^{2}$ After the Porte's declaration of war in November 1710, Peter the Great issued a manifesto to the population of the vassal Ottoman principalities of Moldavia and Wallachia "as well as Greeks, Serbs, Bulgarians, Slovenes, Albanians and other Christian peoples," which announced the struggle for the "liberation of the suffering Christians from the barbarian yoke." 3 Although the expected mobilization of coreligionists largely failed to materialize and the tsar himself suffered defeat on the banks of the Pruth, Catherine II followed the example of her "grandfather Peter" in pledging to "maintain, keep and protect the Orthodox Eastern Christian Greek Church" and to defend "other peoples of the same Orthodox faith."

Although Catherine's appeal to the coreligionists continued the precedent established by Peter the Great, the immediate cause of the Russian-Ottoman war of 1768-1774 was a deep religious conflict along Russia's western frontier. By 1768, the empress became involved in the struggle between the Orthodox and Uniate churches in the Polish-Lithuanian Commonwealth that had lasted since the Union of Brest in 1595. Following the establishment of Moscow's control over the left-bank Ukraine in 1667, influential Ruthenian clergymen in the Russian Orthodox Church

The Carl Beck Papers in Russian and East European Studies

http://carlbeckpapers.pitt.edu | DOI 10.5195/cbp.2015.201 | Number 2401 
hierarchy promoted the idea that the tsardom was the only legitimate object of political allegiance for Orthodox believers in Poland-Lithuania. At the same time, Warsaw's loss of the left-bank Ukraine shifted the balance of power between the two eastern rite confessions in the Commonwealth in favor of the Uniates. Over the next century, the Orthodox community there steadily lost ground despite the guarantee of its rights in the Russian-Polish treaty of Eternal Peace of 1686 and the energetic demarches of Peter the Great and his successors. The growing power imbalance between the ascendant Russia and the declining Commonwealth further aggravated the effect of the merging of political and confessional identities. By the late 1760s, mounting Polish intolerance of the politically suspect Orthodox dissidents clashed with Russia's increasingly aggressive promotion of their rights. Catherine's precarious legitimacy as a ruler added a further twist: protection of Orthodox coreligionists in Catholic Poland helped this German-born princess to prove her "Russianness," whereas her advocacy of religious minority rights strengthened her European image of an enlightened ruler. ${ }^{5}$

By 1768, the Russian troops dispatched to Poland to enforce the political rights of the Orthodox dissidents were in full war against the Catholic Confederation of Bar that had sprung up in defiance of the Russian-supported king Stanislaw August. In August of that year, the Russian Cossack units in pursuit of the Polish confederates crossed the Ottoman border and burned the town of Balta, whereupon the French ambassador in Constantinople Charles Gravier de Vergennes urged the Porte to declare war. Eagerly desired by a leading Catholic power jealous of Russia's dominance in Poland, the Russian-Ottoman war of 1768-1774 may appear a continuation of the Catholic-Orthodox rivalry by other means. ${ }^{6}$ Catherine II herself strengthened this impression when, in her authorization to A. G. Orlov to raise the Porte's Christian subjects, she attributed the break in the Russian-Ottoman relations to "the malice and intrigues of the ill-wishers and enviers of the glory of Our Empire and the truly holy piety of the Greek-Russian Church," clearly implying the activities of the French diplomacy. ${ }^{7}$ The empress declared that she had taken the decision to extend her protection to "the many Orthodox Greek and Slavic peoples that languish under the unbearable yoke of Muslim false belief (nechestie)" in the context of the war that she had been forced to wage "for the glory of the holy Greek-Russian church and its freedom in the lands of Polish-Lithuanian Commonwealth."

Catherine's first war with the Ottoman Empire was thus a consequence of her militant defense of coreligionists' rights in Poland. At the same time, the empress instrumentalized the issue of Orthodoxy in the Commonwealth and the Ottoman Empire in significantly different ways. References to the defense of the Orthodox

The Carl Beck Papers in Russian and East European Studies http://carlbeckpapers.pitt.edu | DOI 10.5195/cbp.2015.201 | Number 2401 
Church in the realm of the sultan were remarkably absent from the war manifesto that Catherine addressed to her own subjects, even though much of the text focused on the travails of Orthodoxy in the Poland. ${ }^{9}$ One could argue that in September 1768, the issue of Russia's coreligionists in the Ottoman Empire still could not have the significance that the war of 1768-1774 helped it to acquire. However, Catherine's second "Turkish war" manifesto of 1787 does not confirm this hypothesis. Similarly to the manifesto of 1768, it spoke of the Porte's violation of the laws of nations and previous Russian-Ottoman treaties. ${ }^{10}$ Some 40 years later, the war manifesto of Nicholas I added the Porte's interference with Russian Black Sea commerce to this list of essentially secular grievances. ${ }^{11}$ Indeed, none of these manifestos vindicated the rights of the Orthodox Church in the Ottoman Empire in order to legitimize the war to the Russian population. ${ }^{12}$ During Catherine's reign and for three or four decades thereafter, protection of Orthodoxy in lands controlled by the sultan was thus by far more important for relations between the tsars and the Ottoman Christians than for the relations between the former and their own subjects.

Moreover, the character and extent of the Russian protectorate over coreligionists in the Ottoman Empire differed significantly from Catherine's prior defense of Orthodoxy in the Polish-Lithuanian Commonwealth. Formalized in the peace treaty of Kuchuk-Kainarji of 1774, this protectorate emerged out of the practical necessity to guarantee the rights and safety of the Christian population in those Ottoman territories that Russia had occupied during the war and subsequently returned to the Porte. As they introduced such guarantees into the 1774 treaty and subsequent Russian-Ottoman agreements, the tsarist diplomats were primarily concerned about possible Muslim reprisals against the local Christians and thought little about the current or future relations between Orthodoxy and other Christian confessions in the realm of the sultan. As a result, the Russian protectorate was defined in a confessionally unspecific terminology and initially applied to particular war-affected provinces with the Christian-majority population rather than to the Greek Orthodox Church of the Ottoman Empire. Activities of the local elites as well as geographic situation and historical circumstances of the Russian-Ottoman rivalry over the territories in question explain further variations in the character and scope of Russian protection, the overview of which is offered in what follows.

Although focused on peace negotiations, this essay seeks to go beyond conventional diplomatic history and reconstruct the political language of protection that in many ways structured the dialogue between Russia, the Ottoman Empire and the Orthodox elites of the latter. In doing so, it draws the theoretical inspiration from the works of the representatives of the Cambridge school of the history of political 
thought. ${ }^{13}$ This school rejected traditional history of ideas focused on big thinkers and instead emphasized the importance of intellectual context. The Cambridge contextualists, as the group came to be known, sought to reconstruct the political languages, or sets of interrelated terms that acquired different shades of meaning in the writings and pronouncements of a wider range of authors engaged in political dialogue. ${ }^{14}$ Understood in this sense, a political language defined the limits of the thinkable within a particular historical epoch and, at the same time, gave expression to the tensions and struggles between a set of political actors. An aspect of the broader turn towards "new political history" in the last decades of the twentieth century, the works of the Cambridge contextualist school contributed to the understanding of political struggle as the struggle for the definition of particular terms and therefore a discursive struggle par excellence.

Informed by this methodology, the present study approaches the transactions between Russia, the Ottoman Empire and the latter's Orthodox subjects as a discursive process, in which actors employed partly overlapping sets of terms to achieve distinct and often conflicting goals. It will be demonstrated that the idiom of protection did not originate in Moscow or St. Petersburg but was suggested to the tsars by the Orthodox elites of the Ottoman Empire, and in particular the boyars of Wallachia and Moldavia, who thereby thought to acquire greater independence from the Porte. With time, the Russian rulers recognized the usefulness of the rhetoric of protection and employed it to mobilize local support at the time of the RussianOttoman wars as well as to contain the Ottoman reprisals against such supporters after the wars were over. Inasmuch as the objectives of Russia and its Orthodox coreligionists matched, they were realized at the expense of the Porte. Since the early 1770s, the Ottoman government repeatedly had to confront the Russian advocacy of the Christian rights in those provinces that served the Russian-Ottoman battleground. At the same time, the reaction of the Orthodox subjects of the sultan to the course of the Russian-Ottoman peace negotiations revealed significant tensions between the "protector" and the "protected." These tensions, likewise expressed in the idiom of protection, constitute an important yet underestimated aspect of the history of the "Eastern Question" that the present paper seeks to highlight. 


\section{Moldavia and Wallachia between the Tsar and the Sultan}

The notion of protection defined the relations between the sultans and the rulers of Moldavia and Wallachia ever since the establishment of the Ottoman dominance on the lower Danube in the late fourteenth and fifteenth century. As long as the Moldavian and Wallachian hospodars and their subjects delivered the assigned tribute and stayed loyal, the Ottomans would prohibit their troops and the Tatar vassals from devastating the principalities, which retained a considerable measure of self-government and remained Christian territories. Protection in return for tax or tribute payment formed the basis of the relations between the Muslim rulers and the conquered non-Muslim populations (zimmi) ever since the early days of Islam and constituted the legal cornerstone of the Ottoman rule in South-Eastern Europe. ${ }^{15}$ In contrast to the territories to the south of the Danube, whose Christian population was placed under the rule of the Ottoman military governors and paid individual poll-tax (cizye), the population of the principalities paid taxes to the hospodars, who used part of this revenue to pay the "communal tribute" (haraç maktu) to the Porte. In this respect, Moldavia and Wallachia belonged to the same category of the Ottoman Empire's Christian dependencies as the principality of Transylvania and the republic of Raguza. ${ }^{16}$ All these self-governing tributary polities existed on the border between the "house of Islam" (dar al Islam) and the "house of war" (dar al harb), into which the Ottoman law of war and peace divided the world. ${ }^{17}$

The position of Moldavia and Wallachia on the fault-line between Islam and Christendom did not remain unchanged, and these changes became reflected in the Ottoman terminology. Whereas in the fifteenth century the Ottoman sources would refer to Moldavia and Wallachia as parts of the "house of war," since the early 1500 s they increasingly redescribed the principalities as part of the "well-protected domains" of the sultan that were "conquered by sword" and "included into the "house of Islam'." 18 The latter assertion was not fully consistent with the principles of Islamic law, since Sharia was never introduced in the principalities. ${ }^{19}$ Nevertheless, this tendency continued in the eighteenth and early nineteenth century, when the sultans called the principalities their "property" and "inheritance." 20

Changes in the terminology reflected the consolidation of the Ottoman dominance over Moldavia and Wallachia, which affected the distribution of power within their elites. The tightening of the Porte's control over the appointment of the hospodars during the sixteenth century contributed to the empowerment of the boyar aristocracy. As a result, the notion of protection that had conditioned the relations 
between the Ottoman sultan and the principalities since the fifteenth century came to influence the local politics. Each hospodar appointed by the Porte was to protect his subjects and could expect destitution and punishment for the failure to do so as reported by the subjects themselves. ${ }^{21}$ This helped the Ottomans to change the hospodars with growing frequency and receive increasingly lavish gifts from each new incumbent in addition to the basic tribute. The side effect of this strategy was an intensification of political infighting, in the course of which segments of the Moldavian and Wallachian elites would turn to other powers in search of a less heavy-handed protector than the sultan.

This was the general political context for the appeals for protection and declarations of loyalty that the hospodars, boyars and high clergymen of Moldavia and Wallachia addressed to the Russian tsars in over a century that preceded the Russian-Ottoman war of 1768-1774. These pleas reveal that the elites of the principalities came to perceive the Muscovite tsars as their intercessors well before the latter were ready and willing to adopt such a posture themselves. In 1656, tsar Alexis Mikhailovich received the first such message from the Moldavian hospodar Gheorghe Ștefan (1653-1658) ${ }^{22}$ yet ultimately decided not to dispatch the embassy to Iași that was supposed to administer the principality's oath of loyalty to the tsar. ${ }^{23}$ Five years later, tsar Alexis mentioned his "old friendship" with the sultan as the reason why he could not accept the Moldavian hospodar Constantin Șerban "under his high hand." ${ }^{24}$ The response of the tsar reflected the same unwillingness to antagonize the Ottomans that in 1642 made his father Mikhail Feodorovich return to the sultan the Azov fortress captured by the Don Cossacks several years previously.

The Ottoman-Russian "friendship" ended only in 1672 after Mehmed IV (1648-1687) invaded Podolia and threatened Moscow's control of the left-bank Ukraine. In the next three decades, nearly continuous hostilities with the Porte made Alexis Mikhailovich and his children more interested in Moldavian and Wallachian overtures. In 1688, the archimandrite of St. Paul's monastery on Mount Athos, Isaiah, brought messages to Moscow from the Wallachian prince Şerban Cantacuzino and the Moldavian prince Constantine Cantemir. ${ }^{25}$ The corulers Ivan V and Peter I as well as Tsarina Sofia responded favorably to Cantacuzino's desire to be "under the high hand of their tsarist majesties" and suggested coordinating the military activities. However, the failure of prince V. V. Golitsyn's the Crimean campaign of 1689 put an end to this rapprochement. ${ }^{26}$ After he assumed the plenitude of power, Peter the Great continued to received requests for protectorate or alliance from the hospodars of the principalities and eventually concluded a treaty with Moldavian prince Dmitrie Cantemir on the eve of the ill-fortuned Pruth campaign of $1711 .^{27}$ 
A brief overview of the conditions of the Russian-Moldavian treaties negotiated up to that historical turning point demonstrates that from the beginning the princes and boyars were ready to place themselves under the "high sovereign hand" of the tsar on certain conditions. These usually included internal autonomy and the preservation of their traditional rights and the laws of the country. Thus, the treaty of 1656 between Gheorghe Ștefan and Alexis Mikhailovich stipulated that the Moldavian hospodar be always elected from among the natives of Moldavia, retain his traditional prerogatives and reestablish his authority over cities alienated into Ottoman-controlled raiale districts. ${ }^{28}$ Similarly, the conditions upon which the Moldavian boyars were ready to swear loyalty to tsar Alexis in 1674 included respect of the "customs of the land" and the right to elect the hospodar as well as the secular and ecclesiastical officials. The boyars also asked to restore the territorial integrity of the principality which, under the influence of Polish political notions, they called a commonwealth (Rechpospolita).$^{29}$ Finally, the diploma issued by Peter the Great to Cantemir secured the latter's hereditary rule over Moldavia and asserted the plenitude of the hospodars' authority over the boyars, the cities, and the Ottoman raiale "in accordance with the ancient Moldavian custom." 30

For almost a century after the Pruth debacle, hardly a Moldavian or Wallachian prince willed or dared to conclude treaties of alliance with or become a subject of the Russian tsar. ${ }^{31}$ The Phanariot Greeks who, after 1711, monopolized the thrones of Moldavia and Wallachia were too closely controlled by the Ottomans and, as cultural foreigners, did not enjoy substantial support of the largely autochthonous boyar class. ${ }^{32}$ On the other hand, the Russian-Ottoman wars of 1735-1739 and 1768-1774 occasioned the formation of pro-Russian "native" boyar factions that perceived Russian rule or protectorate as a means to consolidate their position in the principalities. ${ }^{33}$ In 1736-1737, the Wallachian envoy to Tsarina Anna Ioannovna, Preda Drăgunescu, reported that the boyars of the principality "slavishly request not to leave [them] among other enslaved people, but to deliver [them] and make [them] subjects of Your Orthodox Majesty." ${ }^{34}$ The boyars sought to avoid both the reconsolidation of Ottoman dominance and the imposition of the Habsburg rule. ${ }^{35}$ In anticipation of the Russian-Austrian-Ottoman negotiations at the Congress of Nemirov in July - October 1737, the Wallachians begged the Russian empress "not to leave them subjugated to other nations" in peace or war. ${ }^{36}$ However, the Wallachian fears of remaining in "Turkish enslavement" materialized in September 1739, when the exit from the war of Russia's Habsburg ally forced Anna Ioannovna to conclude her own peace with the sultan that effectively reconfirmed the Ottoman dominance in the entire Black Sea region. This, however, did not happen before

The Carl Beck Papers in Russian and East European Studies http://carlbeckpapers.pitt.edu | DOI 10.5195/cbp.2015.201 | Number 2401 
a brief Russian occupation of Moldavia, in the course of which the principality "accepted with a great and ineffable tearful joy" the authority of the empress. The boyars and the Russian commander-in-chief Burkhart Christoph von Munnich signed a convention, according to which Moldavia relinquished its right to conduct an independent foreign policy and undertook to maintain a 20,000-strong Russian army in return for internal autonomy. ${ }^{37}$

Moldavian and Wallachian elites took considerable risks when they attempted to extricate the principalities from the Ottoman and Phanariot dominance with Russia's help. For various reasons, the treaties of alliance and suzerainty of 1656, 1711 and 1739 remained a dead letter as the tsars either did not want to put them into effect or were prevented from doing so by the force of circumstances. Those boyars and clergymen who collaborated with the Russians during the wars faced severe punishment from the Ottomans, unless they were ready to emigrate after the conclusion of peace, as many did. ${ }^{38}$ And yet, frustration with the rule of the Ottomans and their Phanariot agents explains why in summer and fall 1768 Catherine's emissary lieutenant-colonel N. A. Karazin ${ }^{39}$ could secure support of the commander of the Wallachian military force (spathar) Pârvu Cantacuzino and several high clergymen. ${ }^{40}$ During the campaign of 1769 , Cantacuzino supplied intelligence to the Russians and in November of that year collaborated with Karazin in chasing the small Ottoman garrison from Bucharest and capturing the hospodar Grigore Ghica. ${ }^{41}$ Following the Russian occupation of the Wallachian capital, the boyars addressed a message to Catherine II in which they rejoiced at the first victories of the Russian arms, complained of the three hundred years of Ottoman "tyranny" and asked the empress to "accept them under immediate protection ... by attaching [Wallachia] to the extent of the empire of Your Imperial Majesty." 42

The memory of the negative experiences of 1711 and 1739 prevented the Moldavian elites from committing themselves before the entry of the Russian troops in the principality in late September 1769. Once this happened, the Moldavian clergymen and boyars eagerly kissed the cross and gospel in confirmation of their loyalty to Catherine II. ${ }^{43}$ However, subsequent withdrawal of the bulk of J. K. von Elmpt's corps to the winter quarters in Podolia dampened their enthusiasm as did the Ottoman manifesto that contained a threatening admonition to stay loyal to the sultan. In order to neutralize the effect of the Ottoman announcement, the Russian commander-in-chief P. A. Rumiantsev dispatched Ch. F. von Stoffeln's corps to reoccupy Moldavia and issued his own manifesto promising that the principality will never return to Ottoman rule. ${ }^{44}$ Reassured, the Moldavian Metropolitan Gavriil and senior boyars sent a message to the Russian empress, in which the authors

The Carl Beck Papers in Russian and East European Studies http://carlbeckpapers.pitt.edu | DOI 10.5195/cbp.2015.201 | Number 2401 
likened their travails under Ottoman rule to the persecution of the early Christians. The Moldavians compared Catherine II to the first Christian ruler Constantine the Great and begged her not to leave them, "coreligionists and loyal subjects of Your Imperial Majesty... to the most cruel and ferocious outrage of the evil Christ-haters and aliens." They also asked the empress to let them "always live in quiet and peace under [her] high autocracy." 45

The uncertainty of the Moldavians and Wallachians about their future did not escape the Russian commanders. Major-general A. A. Prozorovskii captured this mood well when he reported from Iași that the "local population . . . is afraid that they will be given back to the Ottomans at the end of the war." ${ }^{\prime 6}$ For their part, the deputies of the Wallachian boyars told Rumiantsev that their eager response to Catherine's call for an anti-Ottoman struggle "embittered the Turks against the country" and made it imperative for the Wallachians "not to be left under Ottoman rule in time of peace." ${ }^{47}$ During the audience with Catherine II, Wallachian deputation asked the empress not to forget their lands during the future peace negotiations with the Ottomans "so that the enemy could not deprive us of your protection . . . and throw us back into the abyss of tyranny." 48

The empress accepted "the submission and the oath of loyalty" of the boyar deputies and assured the Moldavian and Wallachian inhabitants as her coreligionists of "all their Christian rights and privileges." ${ }^{49}$ However, the deputies soon learned from the vice-chancellor N. I. Panin that Catherine II would not insist on the annexation or independence of the principalities in order not to provoke the European powers, who were already worried by the Russian victories over the Ottomans. ${ }^{50} \mathrm{At}$ the same time, the empress and her ministers realized that an unconditional return of Moldavia and Wallachia to the Ottomans would severely undermine Russia's prestige among the Christian subjects of the sultan. To prevent such an outcome, they decided to instrumentalize the issue of Moldavian and Wallachian rights and privileges during the negotiations with the Ottomans. Catherine ordered Panin to require from the Moldavian and Wallachian deputies a description of the state of their lands as well as a statement of their "needs, wants and wishes." 51 The Wallachian deputies promptly provided Panin with the statistical information and complained about frequent changes of the hospodars by the Porte in the last 50 or 60 years as well as exorbitant taxation that violated "the old customs of the land" and led to the depopulation of the principality. ${ }^{52}$

The Russian draft of the peace settlement in March 1771 took account of these remonstrations and presupposed the return of Moldavia and Wallachia to the Porte on condition that the principalities "forever retain the rights and privileges,

The Carl Beck Papers in Russian and East European Studies http://carlbeckpapers.pitt.edu | DOI 10.5195/cbp.2015.201 | Number 2401 
with which they had entered the Turkish overlordship."53 On Panin's suggestion, Catherine envisioned returning Moldavia and Wallachia after a period of peacetime Russian occupation, in the course of which their revenues had to go to the Russian treasury as an off-set to the war contribution that the empress sought to impose upon the Porte as the power "guilty" of the war. Alternatively, she was ready to drop the demand for monetary compensation in return for the Porte's recognition of the independence of the principalities. Placed under the guarantee of Russia, Prussia and Austria, the principalities would serve as a barrier between all the neighboring powers and would make them "unable to fight each other." 54

By the time of the Focșani peace congress in July and August 1772, the Wallachian boyars must have been aware of this proposal. They also knew that Austria and Prussia, who offered their "good councils" during the Russian-Ottoman negotiations, opposed the independence of the principalities because of the power imbalance that it would supposedly create in Russia's favor. To overcome the Prussian and Austrian opposition, the boyars suggested to the Russian representatives at Focșani G. G. Orlov and A. M. Obreskov the idea of placing the principalities under a joint protectorate of Russia, Prussia and Austria and agreed to pay for this protection..$^{55}$ Still willing to "taste the happiness of direct subjection to the all-powerful Empress of Russia," they were also ready to turn Moldavia and Wallachia into vassals of the Polish-Lithuanian Commonwealth in the manner of the Duchy of Courland. According to the boyars this arrangement would "calm things in Poland" after the first partition and secure the principalities their "privileges and exemptions."

Anxious to reaffirm the rights and privileges of Wallachia, the leader of the Wallachian boyars Mihai Cantacuzino also composed an exposé of the original conditions, upon which the medieval princes Mircea the Old (1386-1418) and Laiotă Basarab (1473-1477) had supposedly accepted the Ottoman suzerainty. ${ }^{57}$ A curious example of the invention of a legal tradition, ${ }^{58}$ the exposé affirmed that, in return for a moderate tribute, the Turks agreed "not to meddle into the affairs of the country," 59 which remained free to declare war and conclude peace with its neighbors. According to the Cantacuzino, supreme jurisdiction of the elected native hospodars extended to cases that involved Christians and Turks. The latter were prohibited to construct mosques in the country or even enter it for reasons other than commerce. ${ }^{60}$ The Wallachian leader further argued that the privileges of the principality were decisively violated following the establishment of the Phanariot rule in 1716 that resulted in the destruction of the Wallachian army, acquisition of lands by Muslim proprietors, imposition of the Ottoman commercial monopoly and exorbitant taxation. ${ }^{61}$ 
In parallel, the Moldavian boyars formulated their own version of the original conditions, on which the Moldavian hospodar Bogdan III (1504-1517) "inclined the country to the Turks." According to these conditions, the sultan would have recognized Moldavia as a "free and unsubjected country," guaranteed the freedom of its "Christian religion," promised to protect the country from external enemies and left it "to be governed according to its own laws without the least interference of the Porte." The Muslims were not to buy land in the principality and construct mosques. Under the rule of native hospodars elected for life, Moldavia was free to maintain a 20,000-strong army and appoint its representatives in Constantinople. Submission to the Porte manifested itself only in the hospodar's obligation to report with his troops to the sultan's call in time of war and the payment of a biannual gift of 40,000 golden pieces. ${ }^{62}$ The memoir further traced how, after sixteenth-century infringements upon Moldavia's privileges, Mehmed IV (1648-1687) restored the original conditions of the country's "submission" to the Porte. According to the anonymous author, these lasted until the burning of the original Ottoman hatt- $i$ sherif during the Polish occupation of Iași in 1686, which ushered in a new series violations culminating in the establishment of Phanariot rule in the early $1700 \mathrm{~s} .{ }^{63}$

There is no evidence that Orlov ever raised the issue of the principalities during the Focșani congress, preoccupied as he was with the question of the independence of the Crimean Khanate. After the congress broke up at the end of August and was reconvened again in Bucharest in November 1772, Catherine's representative, A. M. Obreskov, preferred to postpone the discussion on the principalities. He did so out of fear that the news of Russia's return of Moldavia and Wallachia to the Ottomans, however conditional, might affect the attitude of the local population towards the Russian army. This negotiation strategy made the boyars nervous and occasioned yet another round of appeals. Afraid of being delivered "into the hands of our first tormentors," the Moldavian Metropolitan Gedeon implored the commander-in-chief P. A. Rumiantsev to secure for his flock the continued "benevolence and protection of Her Imperial Majesty." ${ }^{64}$ On their part, the Wallachians evoked the manifestos of Catherine II that "announced the liberation to all Christian peoples" as well as the "verbal and written assurances" the empress had given them in St. Petersburg to that effect. They called Obreskov's attention to the "innumerable families that have revealed their zeal for the mighty empire of Russia" and now were afraid of their "complete ruin" should the principality return under "cruel and inhuman slavery." 65

Obreskov assured the worried Wallachians and Moldavians that, whatever might happen, he would take care of their security ${ }^{66}$ and, towards the end of the Bucharest congress, finally disclosed to his Ottoman counterpart Abdur-Rezak "certain 
conditions," upon which Russia was ready to return the principalities to the Ottoman Empire. ${ }^{67}$ The Porte had to pledge "to recognize and respect the clergy with all the distinction due to its rank" as well as "not to impede the practice of the Christian religion" or the (re)construction of churches in the principalities. ${ }^{68}$ The Ottoman government was also not supposed to demand any war contribution; instead it had to annul all past debts of the principalities and grant them an exemption from tribute for 2 years. Moldavian and Wallachian territories illegally alienated into raiale had to be reintegrated into the principalities, which were to "enjoy the same advantages that they had at the time of Mehmed IV." ${ }^{69}$ Finally, the Russian envoys at the Porte would acquire the right to "speak in favor of the two principalities, while the Porte would have to promise "to take these representations into consideration as is done in the relations between friendly and respected powers." 70

Obreskov's proposed clause on the principalities did not meet the Wallachian expectations. A year after the breakup of the Bucharest negotiations, the boyars wrote to Catherine II that the peace terms, which her representative offered to the Ottomans, threw them "into the abyss of sorrow and despair." They referred once again to her manifestos and assurances about the liberation of the principalities and emphasized their contribution to the Russian victories during the war. Unless Russia defended the liberty of the principalities, they argued, the Ottomans "[would] change our mode of government, [transform the principality] into a pashalyk and [would] force the people to change religion." ${ }^{.71}$ As the Russian and the Ottoman representatives were about to resume the final peace talks at Kuchuk-Kainarji in the summer of 1774, the Wallachian leaders obtained Rumiantsev's permission to dispatch Mihai Cantacuzino to St. Petersburg again in order to plead before Catherine II and her ministers for their "salvation and escape from the yoke of tyranny." 72 In parallel, the Wallachian boyars also called on the Russian commander-in-chief to "consolidate the liberty of our people" in the forthcoming negotiations with the Ottomans. They also reiterated the project of placing the principalities in a vassal relation to Poland and under the collective protectorate of Russia, Austria and Prussia if it were impossible for them to remain under the "direct government of the Orthodox and all-powerful empress of Russia."

The actions of the Wallachian boyars in the last months prior to the conclusion of the peace treaty suggest that they reacted to the formulas of the Russian peace proposals. Thus, by June 1774 they were ready to accept for Wallachia the status of the vassal Ottoman republic of Ragusa, which paid its tribute to the Porte only once in 3 years and was represented in the Ottoman capital by a consul. ${ }^{73}$ This formula for the first time figured in Obreskov's draft of the peace treaty at the end of the

The Carl Beck Papers in Russian and East European Studies http://carlbeckpapers.pitt.edu | DOI 10.5195/cbp.2015.201 | Number 2401 
Bucharest congress in March $1773 .{ }^{74}$ When it became clear that their more ambitious schemes would not pass, the Wallachian boyars found in the Ragusan model the minimal provision against the "meddling of the oppressive tyranny into [their] country." "Af After the boyars learned that the peace treaty signed on July 10, 1774 did not mention Ragusa and contained only a reference to "the advantages that the principalities had enjoyed during the reign of Mehmed IV," they hurried to provide Rumiantsev with a detailed description of these privileges. The latter included, among other things, the election of a native hospodar, his supreme jurisdiction in civil and criminal matters involving Christian and Muslim subjects, the prohibition to the Ottoman troops to enter the territory of the principality as well as the liberty of the inhabitants to leave the country for study." 76 Apprised of the newly acquired Russian right to "speak in favor" of the principalities, they sought to reinterpret it as a prerogative for Catherine's envoys to "defend and support the rights of our country in accordance with the treaties." 77

At the same time, one should not take this "reactive" behavior of the boyars in summer 1774 as evidence of their minimal role in the genesis of the KuchukKainarji treaty clause on the principalities. Whether Mihai Cantacuzino's exposé of Wallachian "capitulations" predated or antedated Obreskov's peace proposals and the final treaty ${ }^{78}$ both bore the undeniable influence of the boyar discourse on the "rights and privileges" of the principalities. The delegates of the Wallachian and Moldavian boyars must have suggested to Catherine II and vice-chancellor Panin the idea that Moldavia and Wallachia should "forever retain the rights and privileges with which they had entered the Turkish overlordship." The same applies to the stipulation that committed the Porte to respect "the advantages that the principalities enjoyed during the reign of Mehmed IV." One finds no mentioning of Mehmed IV in Cantacuzino's description of the Wallachian "capitulations," yet this sultan figures prominently in the exposé of Moldavia's original rights under the Ottoman suzerainty. Whatever the actual date of this document, ${ }^{79}$ Obreskov could borrow the reference to Mahmud IV only from its author or someone with a similar interest and stake in the "old privileges" of the principality.

In the decades following the conclusion of the peace of Kuchuk-Kainarji, the Russian protectorate over Moldavia and Wallachia crystallized a set of legal documents and diplomatic practices. Article 16 of the 1774 treaty constituted the legal foundation of the protectorate, which was further clarified in the explanatory convention of Ainaly-Kavak of 1779 and confirmed by the peace treaties of Iași (1792) and Bucharest (1812). ${ }^{80}$ In the wake of each subsequent Russian-Ottoman war, the newly appointed hospodars would receive the Porte's orders to implement 
the stipulations of the treaty in the form of decrees (firman) confirmed by the sultan's apostil (hatt-i sherif). ${ }^{81}$ The hospodars' disrespect of these stipulations (sometimes secretly encouraged by the Porte) would usually lead to the "representations" of the Russian envoys. An important role in this process belonged to the Russian consuls in Bucharest and Iași, to whose appointment the Porte reluctantly agreed in $1782 .{ }^{82}$ Being the first foreign diplomatic agents accredited in the principalities, Catherine's representatives differed much from the commercially-minded Western European consuls in the Levant. ${ }^{83}$ Thus, in addition to the commercial affairs, the agenda of the first Russian consul-general in Bucharest S. L. Lashkarev included collecting intelligence on the Ottoman military preparations on the Danube and "observing the actions of both hospodars." ${ }^{\prime 4}$ His successor I. I. Severin promptly became a contact person for all local discontents and relayed their grievances to the Russian college of foreign affairs. ${ }^{85}$ Written complaints of the Moldavian and Wallachian boyars and high clergy about the policies of the hospodars provided the tsar's envoys in Constantinople with additional evidence necessary to prove the non-observance of these treaties by the Porte. ${ }^{86}$

Russian demarches on behalf of the principalities for the most part had little to do with the Orthodox religion per se. The boyar complaints, consular reports and the "representations" of the envoys almost always referred to the policies of the Greek Phanariot princes who had failed to tax Moldavia and Wallachia "with all due humanity and magnanimity" prescribed by the peace of Kuchuk-Kainarji and ignored the tax exemptions granted to the principalities in the wake of each Russian-Ottoman war. ${ }^{87}$ Protested infringements on the rights of the Orthodox Church concerned the church properties rather than persons of the priests or matters of liturgy. In particular, the Moldavian and Wallachian elites complained of the failure of the Ottoman fortress governors to restore the monastery lands that they had unlawfully incorporated into the raiale districts. ${ }^{88}$

The actions of the Danubian pashas and the Porte's Muslim subjects in the principalities constituted another frequent pretext for Russian interference. The treaty of 1774 prohibited the Ottoman pashas and the governors "to oppress the principalities and demand any payment or tax, however called" beyond those that existed at the time of Mehmed IV. ${ }^{89}$ With the weakening of the Ottoman central authority during the early years of the nineteenth century, this clause became particularly difficult to enforce. In 1802, the Moldavian boyars complained to Alexander I about "the Turks from the fortresses, who take by force our possessions and kill our peasants" as well as those who "under the pretext of commerce settle by the dozens in our trading towns with the intention of destroying our faith and economy." 
a devastating raid of the rebellious pasha of Viddin Pavsand-Oglu into Wallachia served the Russian envoy in Constantinople V. S. Tomara as a pretext to demand a hatt-i sherif that restated Russia's right of protectorate over the principalities. ${ }^{91}$

Although their effect was limited, Russian "representations" about predatory taxation policies of the Phanariot hospodars and the raids of the Danubian pashas illustrate well the self-perpetuating character of St. Petersburg's interferences into the relations between the Ottoman government and its dependencies. With time, these "representations" broadened in scope to include the issue of reform of the Moldavian and Wallachian institutions. The tsar's diplomats gradually came to view political reform in the principalities as means of consolidating Russia's role of the arbiter in the relations between the boyars, the princes and the Porte. Already in 1802, Tomara secured seven-year tenure for the hospodars and made their deposition prior to that term conditional upon Russia's consent. After the Bucharest peace treaty (1812) reaffirmed this principle, the Russian envoys began insisting that the princes rule in cooperation with the boyar divan. Temporarily suspended by the outbreak of the Greek crisis in 1821, this tendency culminated in comprehensive political reorganization of Moldavia and Wallachia under the Russian provisional administration of P. D. Kiselev in 1829-1834. ${ }^{92}$

Russian transactions with the elites of Moldavia and Wallachia from midseventeenth to the early nineteenth century amply illustrate the functioning of the political language of protection within the broader framework of Russia's Eastern policy. The Romanian boyars would usually ask the Russian rulers to take them "under high hand" and restore and protect the "the old customs" or "privileges and exemptions" of the principalities that had been violated by the Ottomans or the Phanariots. For their part, the Russian rulers would ultimately be only too happy to accept "submission and the oath of loyalty" on the part of the boyars and would guarantee their "Christian rights and exemptions." Although these exchanges could look perfectly harmonious to the external observer, the two sides used the same terms to advance their own political interests that overlapped only partially. The boyars did not fail to mention their common religion with the Russians, yet they sought to secure the autonomy of the principalities rather than the interests of the Orthodoxy in general. The boyar vindications of their historical rights served Russians as a pretext for the permanent interference in the relations between the Porte and the principalities. These interventions were supposed to produce the impression that Russia did not abandon its coreligionists and supporters even though it repeatedly agreed to return the principalities to the Ottoman Empire in the wake of each new Russian-Ottoman war. Romanian boyars and Russian statesmen thus used the rhetoric of protection

The Carl Beck Papers in Russian and East European Studies http://carlbeckpapers.pitt.edu | DOI 10.5195/cbp.2015.201 | Number 2401 
in order to pursue two distinct political agendas that did not contradict each other for as long as they could be realized at the expense of progressive diminution of the Ottoman sovereignty over Moldavian and Wallachia. As soon as the peace treaty of Adrianople (1829) turned this sovereignty into pure formality, divergent interests of the Russian empire and the Romanian elites became manifest, and this revealed the new limits to the Russian protectorate over the principalities.

\section{Orthodox Coreligionists in War and Peace}

For eighty years following the conclusion of the Kuchuk-Kainarji treaty, Moldavia and Wallachia remained central to the relations between Russia, the Ottoman government and the Christian subjects of the latter. Through consular and ambassadorial "representations," the Russian Empire exercised a direct and increasingly formal protectorate over the principalities that the Ottomans found difficult to challenge. These Russian-Ottoman transactions not only conditioned the development of Moldavia and Wallachia in the first half of the nineteenth century, but also influenced Muslim-Christian relations in other provinces of the Ottoman Empire. This was especially true of other territories temporarily occupied by the Russian armies in the course of Russian-Ottoman wars and subsequently returned under the Porte's authority.

At the same time, the local conditions in these territories differed significantly from those of Moldavia and Wallachia. Nowhere else could the Russians rely on a fully articulate Christian political elite or make use of the (invented or real) local legal tradition. Unlike these two principalities, all the other parts of Turkey-in-Europe south of the Danube ever occupied by the Russian troops were pashalyks, ruled by the Muslim governors. Although the Russian-Ottoman treaties included provisions guaranteeing the status of Orthodoxy in the temporarily occupied territories of the Balkan peninsula, the legal grounds of Russia's subsequent interference on their behalf remained less clearly defined than was the case of the principalities. As a result, the protection that Catherine and her successors sought to extend to these provinces was more limited in both its scope and duration than the regime of the protectorate established in Moldavia and Wallachia.

Whereas the principalities were the main theatre of the war of 1768-1774, the Russian-Ottoman struggle also involved Morea and the Archipelago. Catherine's decision to call the local population to arms against the Porte fed on the reports of 
her secret emissaries in the Ottoman domains that were dispatched in the early $1760 \mathrm{~s}$ at the first signs of the Porte's hostility to Russian activities in Poland. ${ }^{93}$ Thus, the Greek merchant Manuil Saros, dispatched to Morea to sound out the attitudes of the local Christian population, reported in May 1765 that the leaders of Maina as well as the captains of Lacedaemonia, Xiromero and Himara professed their readiness to make a stand in the case of war between Russian and the Ottoman Empire. ${ }^{94}$ In parallel, Panin received reports on the Mainot defiance of the Porte's authority from the Russian chargé d'affaires in Constantinople P. A. Levashov and the future envoy to the Porte V. S. Tomara, who in the 1760 s had studied in Italy and visited Greece. ${ }^{95}$

On the basis of these reports, Catherine's favorite G. G. Orlov suggested at the session of the State Council in November 1768 "to dispatch to Morea, Dalmatia, Georgia as well as all our coreligionists in Turkish realm" the news that Russia is forced to fight with the Turks "a war for religion." "96 Attracted to Orlov's project of "liberation of the peoples of the Greek religion from the Ottoman yoke,"97 the empress dispatched a number of emissaries into the European domains of the sultan. Alongside the already mentioned N. A. Karazin who liaised with the Wallachians, M. Ia. Ezdemirovich and Efim Belich brought Catherine's message to the inhabitants of Montenegro, while I. I. Petushin carried a similarly worded letter of the Russian vice-chancellor N. I. Panin to the Albanian leader Bukoval and the Mainot leader Mavromichalis.

In her relations with the Ottoman Christians to the south of the Danube, Catherine II continued the precedent established by Peter the Great. Appraised through the Herzegovinian nobleman Sava Vladislavich-Raguzinsky of the Montenegrin defiance of the Porte's authority, the tsar-reformer called the local prince-bishop Danilo Petrović Njegoš to raise arms in a message that spoke of the suffering of the "Christian Church" and "Christian flock" under the rule of the Ottomans "barbarians." ${ }^{\text {" }}$ Although unsuccessful, the first attempt at RussianMontenegrin military cooperation established a lasting relationship, sustained by the periodic visits of the Montenegrin leaders to Russia and no less frequent missions of the tsars' emissaries to Montenegro. ${ }^{99}$ However, these relations were not free of mutual frustrations partly because the successors of Peter the Great had little use of Montenegrin bellicosity or found the local warrior society too unruly. ${ }^{100}$ The affair of the "pretender" Śćepan Mali, who claimed to be Catherine II's deposed husband Peter III, further complicated the situation on the eve of the war of 1768-1774. ${ }^{101}$ Although the empress still viewed Montenegro as a potential ally, ${ }^{102}$ one can also see why she turned an eager ear to the reports of anti-Ottoman attitudes in other parts of the Ottoman Empire. In January 1769, a number of Morean captains indeed 
confirmed their readiness to fight "the evil Dragon, who had destroyed our race" and "began to spill its poison... upon your imperial and sacred state."103

The actual plan of the Mediterranean expedition belonged to the already mentioned Manuil Saros, who suggested to G. G. Orlov to dispatch a squadron of 10 warships to the shores of Greece, which would rally the Greeks sailors and provide them with guns. ${ }^{104}$ Morea's comfortable harbors and numerous sailors, scarcity of Muslims and weakness of their defenses, would help the local inhabitants win their independence with but little Russian assistance. According to Orlov's Greek liaison, the capture of the isthmus of Corinth would bring Albania, Epirus, Zante and Cephalonia to the side of the insurgents, whereupon they and the Russian navy could blockade the Dardanelles. ${ }^{105}$ After A. G. Orlov reported from Venice about the "numerous and courageous coreligionists willing to serve under our command" against the Ottomans, ${ }^{106}$ Catherine II endorsed what she called "a diversion on the side of Greece," and charged the brother of her favorite with its implementation. ${ }^{107}$

Catherine II's subsequent correspondence with A. G. Orlov reveals her usual attention to the public relations aspect of the operation. ${ }^{108}$ Although in her messages to the Ottoman Greeks and Slavs, the empress invoked common Orthodoxy, she was also eager to render the anti-Ottoman uprising the character of a universal Christian, rather than the specifically Orthodox, struggle. In this way, Catherine II sought to take advantage of the benevolent neutrality of the Protestant powers and, at the same time, neutralize the hostility of the Catholic states. Accordingly, the empress instructed Orlov to act with an eye on the European Respublica Christiana. In a characteristic passage, she urged the Russian commander to rally "different Greek peoples... into a new and united corps" so that this "new member of the Christian republic" would thereupon be able to appeal to "all sovereigns and provinces to recognize them in this capacity and render them, whenever possible, all matter of help and protection." 109

However, by the time Catherine wrote these words, the Morean uprising was over. In early 1770, the Russian navy in the Mediterranean captured the port of Modon and landed a small Russian detachment on the peninsula. What came to be known as the "Orlov rebellion" proved to be a dismal failure due to the scarcity of the Russian troops, the unruliness of the insurgents as well as inadequate coordination between them. ${ }^{110}$ The Ottomans managed to quickly crush the uprising by enlisting the help of the Muslim Albanians, who descended upon the peninsula and severely reprised the Morean Christians for the earlier excesses of the rebels against the Muslims of Mistra. ${ }^{111}$ Although the destruction of the Ottoman fleet at Chesme in late June 1770 and the imposition of Russian control on the Archipelago seriously

The Carl Beck Papers in Russian and East European Studies http://carlbeckpapers.pitt.edu | DOI 10.5195/cbp.2015.201 | Number 2401 
undermined the sultan's ability to fight, Catherine II's fateful decision to spark an anti-Ottoman uprising and the Porte's reprisal measures disrupted Muslim-Christian relations in the region.

After the Morean rebellion failed, Catherine II approved Orlov's decision to withdraw the Russian detachments from Morea and seek instead the destruction of the Ottoman navy. She followed her commander in blaming the Greeks for "not being willing to extract themselves from the yoke of slavery that their own timidity, inconstancy and deceitfulness perpetuated." 112 At the same time, the empress and her advisors recognized the necessity to keep her earlier promise to "include into the future peace treaty with the Porte the friends of Our empire... who join our cause in the war." 113 Vice-chancellor Panin suggested that Russian peace proposals include the demand of "a general amnesty of those who raised arms for the sake of self-defense." 114 Accordingly, the first Russian version of the prospective peace insisted that "Turkish justice give a more active protection against violent oppression of the Christian churches by the provincial governors, as is constantly provided in Russia to the subjects of Muslim faith." 115 The demands for amnesty and religious protection were soon combined and given the character of reciprocity. When in March 1771, Catherine instructed A. G. Orlov to make peace overtures to the Ottomans, her peace conditions included a bilateral general amnesty to all Christian and Muslim peoples who took part in the war as well as of "greater security and freedom of the two religions in the lands both empires." 116

These proposals should be placed in the context of reports of the massacres of the Christian population in Morea and Western Anatolia since the beginning of the Archipelago expedition. Thus, British captain S. G. Goodall, who served as a liaison between the British and the Russian navy, wrote of 30,000 Greeks whom the Turks had supposedly murdered since the departure of Orlov from Morea. Goodall also reported a Greek uprising on the island of Crete as well as "a great insurrection" in Constantinople following the Russian victory at Chesme, at the news of which the Turks supposedly "murdered all the Christians they could meet." 117 Although exaggerated, such reports were not entirely groundless as is clear from the messages Orlov received from Smyrna in the wake of his triumph at Chesme. According to the consuls of the European powers, at the news of Russian victory, "the [Muslim] population and [Ottoman] troops of the city... attacked all the Greeks in the streets and cut a great number of them," killed two Europeans, horrified all the rest and brought commerce to a standstill. Although passions had since calmed down and "commerce had begun to resume its activity," the consuls sought to "dissuade the 
Russian commander from the project of turning the victorious arms of Her Imperial Majesty against a merchant city."118

Although the European consuls were terrified by the "insolent deeds" of the populace and the janissaries, they also testified to the honest behavior of the local Ottoman administration that "had no part whatsoever" in the atrocities, and in fact "labored... with the danger to their lives in order to restore calm and quiet." "119 For their part, the Ottoman authorities confirmed their commitment to maintain order. In his own letter to Orlov, the janissary aga of Smyrna Seid Hasan admitted that, upon receipt of the "sad news" from Chesme, a great crowd of people who had come to the city from the environs, "stirred a perturbation among the inhabitants, in which many reaya died." At the same time, the aga affirmed, with reference to the kadi of Smyrna, that "our law prohibits us to kill any reaya who pays tribute" and assured the Russian commander that the murderers "will suffer the punishment of retribution should the heirs of the victims demand satisfaction." 120

The Muslim-Christian clashes that accompanied the actions of the Orlov's squadron in the Aegean posed the problem of the Orthodox coreligionists in some 20 islands of the Archipelago that fell under Russian control in the wake of Chesme. From the very beginning neither Catherine II nor any of her commanders believed that the Archipelago could remain a Russian possession after the war. Although in March 1771, the empress suggested the principle of uti possidetis, the Aegean islands were not among the list of territories the annexation or independence of which she envisioned as a means of reducing the Porte's ability to attack Russia in future. ${ }^{121}$ The maritime powers would have hardly tolerated Russian annexation of the Archipelago, as Catherine II realized only too well. And then, A. G. Orlov himself dissuaded the empress from her initial idea of retaining several islands, ports and naval bases, pointing to cost of maintaining them and the secondary importance of the Mediterranean, as opposed to the Black Sea, to the Russian commerce. ${ }^{122}$

In the early 1770s, the Archipelago presented the same problem for Russia's Eastern policy as did the principalities. Catherine could not avoid returning the islands to the Ottomans following the conclusion of peace, and yet, she anticipated reprisals against Russia's coreligionists here similar to those that already took place in Morea and Western Anatolia. In order to retain influence upon the Archipelago Greeks it was imperative to include into the peace treaty some sort of guarantee of their post-war security. It is likely that Moldavia and Wallachia served as a reference point to Catherine in her approach to the problem of the islands. Already in 1770, she wanted Orlov to "stipulate some advantages in their favor" such as the right "not to have a Turkish governor or to collect themselves the tribute." Under the possible 
influence of the boyar vindications of the historical rights of the principalities, the empress believed that "some of the islands indeed [had] had these privileges" in the past and even "[had] had the right to kill a kadi if he came to them after they had paid their [yearly] tribute" to the Porte. Catherine II clearly placed the islands in the same category as Moldavia and Wallachia, when she argued that "their internal jurisdiction belongs to themselves" and that "this form of government is considered the best [among] the Turkish subject peoples." 123

In reality, the situation of the Archipelago was considerably different from that of the principalities. In the absence of a distinct aristocracy, senior Greek Orthodox clergymen shared authority with the lay community leaders (primates). Whereas the Moldavians and Wallachians resisted the Phanariots as culturally foreign, the bishops of the Archipelago were co-ethnics of both the primates and the majority of commoners. The Moldavian and Wallachian boyars viewed the Russian intervention as a means to restore their traditional political and social dominance in the principalities that the Phanariot rule had compromised. By contrast, the primates and clergymen essentially accommodated themselves with the Ottoman rule. The former collected taxes for the Porte, while the latter owed their appointments to the Ecumenical Patriarch of Constantinople, who had no choice but to cooperate closely with the Ottomans. ${ }^{124}$ It is significant that the clergymen asked Catherine II "to accept their unhappy Archipelago into eternal defense and protection" only after Orlov's deputy vice-admiral G. A. Spiridov prompted them to do so in January $1771 .{ }^{125}$

Even more importantly, neither the primates nor the clergymen of the islands had the sophisticated political ideas of the boyars. In their relations with the Russian commander, the Orthodox hierarchs of the Archipelago did not go beyond the questions of canonical courts, taxation of clergy and monasteries, itinerant monks, church property and relations between clergy and laity. ${ }^{126}$ In this situation, Catherine II and her agents themselves put forward different projects of political organization of the islands. Their starting point was the empress's instruction to A. G. Orlov to compose out of the Greek peoples "a new and united corps" that would be able to appeal to the "Christian republic" for help. In a parallel letter to Orlov, N. I. Panin defined this corps as an assembly of elected deputies of each province united in confederation. The vice-chancellor suggested the "separation of the Dutch provinces from the tyrannical authority of Spanish monarchy" as a relevant example and considered the Dutch United States of the Netherlands "a form of government... appropriate to the current state of Greece." At the same time, Panin foresaw "insurmountable obstacles" unless Orlov managed to enlist "enlightened, firm and deft" natives who would be able to "prevail over all local souls." 27 
A survey of Russian state-building efforts in the Archipelago in 1771-1774 suggests that elite of this kind did not materialize. ${ }^{128}$ Following the proclamation of the "Archduchy of the Archipelago," in early 1771, Spiridov ordered the election of three "deputies" on each island and placed a "deputy general" Anton Psarro, a Russian naval officer born on Mykonos, in charge of the central government. And yet, as Psarro's letters indicate, the "Archduchy" remained a highly amorphous entity, despite Spiridov's admonitions that, unless united, the islands had no chance of enjoying their liberty after the departure of the Russian fleet. ${ }^{129}$ Although the Russian authorities received spontaneous appeals for protection from particular islands, the clergymen and primates did not submit any collective vindications of historical "rights and privileges" that would be common to the entire "Archduchy." Unlike the Moldavian and Wallachian boyars, the leaders of the islands did not attempt to dispatch a collective delegation to St. Petersburg and were not present at the peace negotiations at Focşani and Bucharest in July 1772 - March 1773, where Obreskov drafted the basic clauses of the Russian-Ottoman peace treaty.

As a result, the draft article on the Archipelago represented an elaboration on Catherine's initial demand of general amnesty and greater security of the "Christian religion," but lacked any provisions that could serve as the basis of political autonomy of the "Archduchy" following its reintegration into the Ottoman Empire. As was the case with the principalities, the Porte had to promise that "the Christian religion and its churches will not suffer the slightest oppression." The Ottoman government was not supposed to prevent "the rebuilding and restoration" of the churches and had to make sure that "their servitors are not insulted or oppressed." The Archipelago islands were to remain free from war contribution and enjoy the same two-year tax exemption as Moldavia and Wallachia, while their inhabitants were free to emigrate during a year and a half following the conclusion of the treaty. ${ }^{130}$ As he read these clauses, the Ottoman representative Abdur-Rezak complained to Obreskov that thereby the lawful sovereign had to remunerate his disobedient subjects after they had helped the enemy. According to the Ottoman negotiator, "this is the same as telling them: 'You will do the same next time and will be rewarded rather than punished."'131 The Russian envoy countered that it was "the custom of all European powers to demand something in favor of the territories that by the right of war belonged for some time to a foreign power which had conquered them."132

Although the peace treaty article on the Archipelago had many similarities with the immediately preceding one on the Danubian principalities, it did not specifically empower the Russian envoys in Constantinople to "speak in favor" of the islands. Nor did it contain any references to the particular local "privileges and advantages," the

The Carl Beck Papers in Russian and East European Studies http://carlbeckpapers.pitt.edu | DOI 10.5195/cbp.2015.201 | Number 2401 
violations of which could serve as a pretext for "representations" of Ivan Voinovich, appointed the Russian consul-general in the Archipelago in 1776, or of the Russian consuls and vice-consuls assigned in 1784-1785 to Chios, Samos, Negroponte and Santorin. ${ }^{133}$ The absence of a politically articulate elite and a developed local legal tradition in the islands at the moment of Russian occupation helps explain why, in the decades following 1774, there did not emerge a Russian "protectorate" over the Archipelago in the sense of systematic diplomatic interventions on behalf of this particular Ottoman Christian territory as was the case of the principalities.

Instead, Russian "protection" here followed the patterns established by the British, French and other European consular networks in the Levant. ${ }^{134}$ Russia's primary interest in the region consisted in placing itself on par with the maritime powers in the affairs of commerce, in which numerous Greek subjects of the sultan participated under the Russian colors after $1774 .{ }^{135}$ In contrast to Catherine's representatives in the Danubian principalities, her agents in the Archipelago and the Levant more broadly were instructed to place the interests of the Russian commerce on top of the agenda and claim "only those liberties that are customarily accorded to the consuls of other rulers." 136 The difference of ethnic origin and social standing of the Danubian and Archipelago consuls corresponded to the different tasks that they were charged with. The tsar's representatives in Bucharest and Iași were relatively high-ranking civil officials who could inspire respect in both the hospodars and the boyars. By contrast, Russia's agents in the Archipelago were recruited on the spot from the natives who had joined Orlov's Mediterranean squadron in 1770-1774. This background made the Archipelago consuls fit for selling protective "patents" (berats) to local merchants and shipmen, ${ }^{137}$ yet they were hardly able to challenge the Ottoman Capudan-pasha on the political rights of the entire region that was within his jurisdiction.

\section{Protection of Coreligionists after Kuchuk-Kainarji}

During the Russian-Ottoman peace negotiations in Bucharest in fall and winter 1772-1773, former Wallachian hospodar Grigore Ghica transmitted to Obreskov a petition of the Greek merchants of Constantinople. The latter complained of not having a single church in Pera at the time when each European power had several churches for the use of their respective trading "nations." The petitioners were ready to assume the construction costs, yet suggested that the church in question be under 
the jurisdiction of the Russian diplomatic mission. "Only in this case, they argued, the Church can be constructed and enjoy the protection of Her Imperial Majesty as belonging to your court." 138 Obreskov on his own initiative added the corresponding clause to the Russian project of the future peace justifying his action by reference to many similar petitions that he had received during his eighteen-year tenure as the Russian envoy in Constantinople. ${ }^{139}$ As a result, according to article 14 of the Kuchuk-Kainarji treaty, Russia obtained the right to construct on the Bei-Oglu street in Pera "a public church of Greco-Russian confession" that would "forever remain under protection of the envoys of [the Russian] empire and will not be subject to any oppression or insult." ${ }^{140}$ Article 7 of the treaty granted the Russian ministers in Constantinople "the right to make various representations in all matters related to this church and its servitors", while the Porte pledged to "take these representations into consideration as coming from a neighboring and sincerely friendly power." 141

Another of Obreskov's initiatives consisted in securing after future Russian envoys in Constantinople the right to offer "some protection" to the Ottoman Christians in general. In his proposed formula, the Porte had to "protect the Christian religion and its churches with great diligence and always accept the moderate representations in favor of these churches made by the Russian ministers." ${ }^{142}$ AbdurRezak immediately opposed this clause, which, in Obreskov's own recognition, "could not be grounded in any [existing Russian] right." 143 The Russian diplomat did not want to "shock the Porte" and was ready to soften further the already "moderate terms," in which he had made his initial proposal. As a result, the draft of the peace treaty which Obreskov presented to his Ottoman counterpart at the end of the Bucharest negotiations in March 1773 contained only the Porte's general promise "to offer a firm protection to the Christian religion and its churches" and expressly enabled the Russian diplomats to "make representations" only with respect to the Danubian principalities and the Bei-Oglu church.

Remarkably enough, the Porte's commitment to protection of its Christians subjects and its promise to receive favorably the representations of the Russian ministers on behalf of the Bei-Oglu church were included into one article (art. 7 of the treaty). ${ }^{144}$ The junction of the general stipulations in favor of the Christian reaya with Russia's right to built and remonstrate on behalf of a particular church may appear as an intentionally created loophole, allowing the tsarist diplomacy to claim later the right to "speak in favor of" the entire Orthodox Church in the Ottoman Empire. In a well-argued analysis of the meaning of Kuchuk-Kainarji treaty, the Ottomanist scholar Roderic Davison demonstrated that the French translation of the treaty published by the Russian government soon after the conclusion of peace 
used the term "Greek" rather than "Greco-Russian" when speaking of the Bei-Oglu church. ${ }^{145}$ According to Davison, this was a "hoax... successfully foisted on Europe" in order to make the European diplomats think that the Bei-Oglu church would be not "a national Russian church," ${ }^{146}$ but an ordinary "Greek" one, and that the right of remonstration in its favor was tantamount to the right of protectorate over all Orthodox churches in the Ottoman Empire. The Ottomanist scholar further pointed to the peace manifesto, in which Catherine II announced to her subjects that "Our Orthodoxy is henceforth under Imperial Guardianship in places of its upspringing, protected from all oppression and violence."147

According to Davison, both the mistranslation of the name of the church and the wording of the peace manifesto reveal the attempt of Catherine II to claim protectorate over the entire Orthodox millet of the Ottoman Empire, contrary to the literal meaning of the treaty that defined such protectorate as the attribute of the sultan. ${ }^{148}$ Indeed in April 1775, the empress instructed her extraordinary ambassador to the Porte N. V. Repnin to "make sure that our coreligionists are nowhere oppressed because of their faith." Repnin was supposed to intercede for Orthodoxy and its churches on the basis of articles 8,14, 16 and 17 of the treaty and demand a quick correction of disorders and strict guarantees against them for the future. ${ }^{149}$ However, in practice the majority of the Porte's Christians remained beyond the scope of the remonstrations made by Repnin or any of the permanent Russian envoys in Constantinople during the late eighteenth century. The only articulate political elite that Repnin encountered on his way to Constantinople were the Moldavian and Wallachian boyars, who did not miss the opportunity to restate their historical rights and privileges. ${ }^{150}$ By contrast, the championship of the interests of the Slavic peoples was not part of Catherine's agenda within the framework of the "Greek project." Having concluded an alliance with the Habsburg Monarchy against the Ottoman Empire, the empress viewed the Westerns Balkans as the Austrian sphere of interests. Her relations with Montenegro remained strained and, mindful of the Habsburg sensibilities, she ignored the Serbian appeals for protection against the increasingly unruly janissaries. ${ }^{151}$

Instead, Catherine II and her successors sought to consolidate their protectorate over the Danubian principalities and extend it to other Christian majority territories that in the late 1700 s and early 1800 s were temporarily occupied by the Russian troops and subsequently returned under the Porte's authority. During the war of 1787-1791, the hostility of Sweden and Britain deprived Catherine II of the possibility of making another "diversion on the side of Greece," 152 and the empress had be content with the reconfirmation of her protectorate over Moldavia and Wallachia in the peace treaty of Iaşi of $1791 .{ }^{153}$ After her death, the Russian-Ottoman rapprochement permitted 
Paul I and Alexander I to extend temporarily their protectorate to so-called Venetian Albania. This narrow strip of land along the Epirote littoral with the towns of Preveza, Parga, Vonizza and Butrinto passed from the Ottoman Empire to the Republic of St. Marco in accordance with the peace of Passarowitz of 1718. Following Napoleon's conquest of Venice in 1797, the area was temporarily claimed by France together with the Ionian Islands and some other possessions of the Venetian Republic. Growing French influence in the Balkans and Napoleon's Egyptian expedition of 1798 made Paul I and Selim III (1789-1807) conclude an alliance, whereupon a combined Russian-Ottoman fleet dislodged the French garrison from Corfu and placed the Ionian Islands under Russian control until 1807. ${ }^{154}$

The Russian-Ottoman convention of Constantinople signed on March 21, 1800, announced the establishment of the Septinsular Republic on the model of Ragusa under the nominal suzerainty of the sultan and Russia's exclusive "guarantee."155 While the convention stipulated formal incorporation of Venetian Albania into the Ottoman Empire, it also reserved to the local Orthodox population the "privileges concerning the matters of faith and civil law" and denied to the Muslims the right of settlement and real estate ownership "on the example of the principalities of Moldavia and Wallachia." 156 Until the outbreak of the new Russian-Ottoman war six years later, the depredations of the pasha of Ianina Ali Tepelena against the local Orthodox population served as a pretext for Russian "representations" on behalf of Venetian Albania before the Ottoman government. ${ }^{157}$

It was during the period of the Russian-Ottoman alliance that Alexander I made an attempt to interpose himself into the relations between the sultan and the entire Christian reaya. It is significant however that the tsar did not try to justify this intervention by reference to the past Russian-Ottoman treaties. The idea of "amelioration of the sort of the Christian subjects of the Porte" constituted an aspect of new political settlement of Europe based on quasi-constitutionalist foundations that the tsar and his de facto foreign minister at the time Adam Czartoryski proposed to the British government in order to contain Napoleon. In his guidelines to $\mathrm{N}$. N. Novosil'tsev who was specially dispatched to London to propose this broad vision to the British, Alexander I spoke, among other things, about the necessity to "assure a happier existence to the Christian peoples chafing under the domination of the Porte," which would "render the latter less precarious" in the face of French expansionism. ${ }^{158}$ In parallel, the tsar instructed his ambassador in Constantinople A. Ia. Italinskii to convince the Ottoman government that at least a partial improvement of the conditions of the sultan's Christian subjects was "one of the surest ways of consolidating the strength of the Turkish Empire."159 
In accordance with this policy, the project of a renewed Russian-Ottoman treaty of alliance drafted in St. Petersburg in December 1804 contained an article that would oblige the Porte to guarantee to the entire Christian population of the European provinces their religious freedom as well as the benefit of all the civil laws, prerogatives and privileges enjoyed by the Muslims. ${ }^{160}$ The Russians also sought to obtain the formal pledge of the Ottoman government to respect the rights of the patriarch of Constantinople and his bishops. ${ }^{161}$ Alongside the advocacy of the interests of the Ottoman Christian population as a whole, the projected treaty contained clauses that had to confirm Russia's rights of protection over particular territories of the Ottoman Empire stipulated in previous Russian-Ottoman treaties. ${ }^{162}$ Finally, the Russian side also sought to include into the treaty a formal guarantee of the territorial integrity of Montenegro against any hostile designs of the pashas of Skutari and Bassano. In order to justify this clause, the authors of the draft evoked the protection that the Russian rulers offered to the inhabitants of Montenegro "since the time immemorial." 163

The sultan's response to the Russian project of the alliance treaty stressed that protection of the Christian reaya was his own duty in accordance with the Sharia law. At the same time, Selim III rejected the idea of equalizing the legal status of Christians and Muslims as being "contrary to [Ottoman] political and religious principles." ${ }^{\prime 64}$ Accordingly, the actual Russian-Ottoman treaty signed in September 1805 recognized Russia's right to "make presentations" on behalf of Venetian Albania, but omitted any reference to the rights of the entire Christian reaya of the European provinces in general or the inhabitants of Montenegro in particular. ${ }^{165}$ The fact that the sultan agreed to the clause with respect to the Venetian Albania, but rejected the one on Montenegro demonstrates that the Ottoman government accepted Russian "protectorate" only with respect to those territories that had been stipulated in previous treaties.

Confronted with the Ottoman opposition to his advocacy of the interests of the Ottoman Christians in general, Alexander I limited himself to reassuring the sultan that the rejected articles were actually meant to strengthen of the Ottoman Empire. ${ }^{166}$ At the same time, the tsar insisted that the sultan restrains the rebellious pasha of Viddin Pavsand Oglu and thereby "restores the tranquility and security of Moldavia and Wallachia," whose "existence and happiness" Russia "guaranteed by virtue of treaties concluded between the two states." 167 Alexander I thus evoked the past treaties to reaffirm his protection over the Danubian principalities, but did not yet try to use them in order to buttress his advocacy of the improvement of the conditions of the Orthodox reaya as a whole. This episode demonstrates, that as late as 1805 , 
neither Kuchuk-Kainarji nor any subsequent Russian-Ottoman agreements served to legitimize Russian claim for protectorate over the entire Orthodox community in the Ottoman Empire.

Instead, Russia continued to view the peace treaties as a means to assert its protectorate over particular Christian majority territories of the Ottoman Empire that under various circumstances temporarily entered into the Russian orbit and later returned under the Porte's authority. This tendency finds illustration in the RussianSerbian relations during and after the First Serbian Uprising (1804-1813). In 1804, the Serbs rose against the excesses of the local janissaries and asked Alexander I to intercede for them before the sultan. ${ }^{168}$ Still eager to maintain the Russian-Ottoman alliance, the Russian foreign ministry wanted the insurgents to pledge their loyalty to the sultan and proposed a wide internal autonomy of Serbia under the Russian and Austrian guarantee as a means to restore the Porte's authority over the province. ${ }^{169}$ Prompted by the tsar's diplomats, the Serbian leaders dispatched a deputation to Alexander I with the request to secure for their country the status of Septinsular Republic, i. e. under nominal suzerainty of the sultan and Russia's protectorate. ${ }^{170} \mathrm{In}$ the following two years, St. Petersburg de facto "spoke in favor of" Serbia before the Porte, yet, in doing so, the Russian diplomats expressly avoided any claims to formal protectorate over the province on the basis of previous Russian-Ottoman treaties. ${ }^{171}$

The situation changed with the outbreak of a new Russian-Ottoman war in December 1806. By this time, the Serbian rising had evolved from an attempt to restore the authority of Selim III over his rebellious Muslim subjects in the Belgrade pashalyk into an increasingly anti-Ottoman movement, whose goal was to achieve the fullest possible autonomy of the "Serbian lands." For their part, the Russians found in the Serbian uprising a means to compensate for their military weakness on the Danube at a time when the bulk of the Russian forces confronted Napoleon in Poland and Eastern Prussia. As a result, the Russian commander-in-chief I. I. Mikhelson admonished the Serbian leader Karageorge Petrović to reject the Porte's proposals, for reconciliation, to "pin his hopes on Alexander" and to support the Russian army by attacking Viddin, the capture of which would "consolidate forever the independence and peace of the Serbian people." 172

In their relations with the tsar, his diplomats and commanders, the leaders of the uprising and their deputies behaved similarly to the Moldavian and Wallachian boyars, although they never quite matched the latter in the degree of political sophistication. Similarly to the boyars, the Serbian leaders disliked the Greeks and feared that their demand for autonomy under a Christian prince could result in the transformation of Serbia into a third Phanariot principality. ${ }^{173}$ At the same time, they 
did not attempt to present this demand as the restoration of the "rights and privileges" of the land that the early sultans had recognized and their successors violated. ${ }^{174}$ Instead, the Serbs demanded self-rule or independence under Russian protection as a guarantee against the ultimate ruin of their people and faith at the hands of the unruly Ottoman janissaries and pashas. ${ }^{175}$ Finally, internal divisions that had plagued the Serbian leadership during the uprising contrasted to the boyars' single-minded promotion of their interests in the early 1770s. ${ }^{176}$ And yet, despite these divisions, the emergent Serbian elite shared a commitment to the unity and distinctness of the province that the clergymen and primates of the Archipelago lacked. As a result, Russian interventions on behalf of Serbia were more consequential than was the case of the Archipelago, even though the Russian diplomats did not quite manage to formalize the tsar's protectorate over this Ottoman province in the peace treaty of Bucharest (1812).

As was the case of the Danubian principalities and the Archipelago in 17701774 , the presence of the Russian troops in Serbia in 1807-1812 served as a pretext for the inclusion of provisions in favor of this province into the Russian-Ottoman agreements. ${ }^{177}$ Thus, during the negotiation of the eighteen-month Russian-Ottoman armistice of Slobodzeia in August 1807, the Russian representative S. L. Lashkarev was unable to extend the truce to the entire Serbia, yet he insisted that it applies to the territories of Viddin and Feth-Islam, "where the Russian troops join the Serbian forces." ${ }^{178}$ Considerations of military honor joined political expediency in the formulation of this demand. Thus, on the day of his death, the commander-inchief Mikhelson confessed to his successor, prince A. A. Prozorovskii, that he felt "ashamed to leave [the Serbs] victims of their loyalty to Russia" especially since "Napoleon always supported his own allies." 179 Although Prozorovskii at one point proved to be ready to sacrifice the Serbian cause to Russia's national interests, ${ }^{180}$ in his transactions with the Porte the prince treated the Serbs as Russia's comradesin-arms and warned the Ottomans in April 1808 that an attack on them would be considered a violation of the armistice. ${ }^{181}$

The Serbian leaders responded to the Slobodzeia armistice and subsequent Russian peace proposals in much the same way in which the Moldavian and Wallachian boyars reacted to Catherine's decision to return the principalities to the Ottoman Empire some 35 years previously. Having risen with great courage against the "enemies of the Orthodox faith," the Serbs "despaired" at the failure of the armistice to stipulate expressly in their favor. ${ }^{182}$ Although Prozorovskii assured Karageorge that the Russian emperor would "not omit anything conducive of the well-being of your land" during the negotiation of the peace treaty, ${ }^{183}$ the 
Serbs complained of "utter uncertainty" about the future that "always confuses the heart and reduces the zeal." 184 Desirous of complete independence, the Serbs were disappointed with the first version of the Russian peace proposals of October 1808 that included the demand of a Serbian autonomy "under the protection of Russia." 185 Karageorge's deputies cited Mikhelson's written and oral declarations which "solemnly promised that Serbia will never be under the Turkish rule again," 186 and demanded the conclusion of "secrete and clear articles" of the Russian-Serbian alliance. The Serbs were ready to join Russia in any war and conclude peace only on its sanction. In return, Russia had to recognize the Serbian people as "independent," guarantee to Serbia the integrity of its territories and promise not to make any decision with respect to the country in the absence of the Serbian deputies. ${ }^{187}$

With the resumption of Russian-Ottoman hostilities in March 1809, Alexander I sanctioned Prozorovskii to promise to the Serbs their complete independence from the Porte, ${ }^{188}$ yet by the end of the year the emperor and his commanders returned to the formula of Serbian autonomy under a Russian guarantee. ${ }^{189}$ For this reason, P. I. Bagration, who stepped in after Prozorovskii's death in August 1809, considered it necessary to decline the request of a new Serbian delegation to accept Serbia under the direct rule of Russia. ${ }^{190}$ Similarly, Bagration's own successor N. M. Kamenskii turned down the invitation of the Serbian leaders to appoint two Russian officials to draw a Serbian code of laws and instructed his representative in Belgrade, F. Nedoba, not to interfere directly into administrative matters. ${ }^{191}$ At the same time, both commanders tried to rally the Serbs after severe defeats that the latter had suffered in the campaign of 1809, and assured the insurgents of "certain fulfilment of hopes that [they] pinned on Russia."'192

According to the February 1810 draft of the peace treaty article on Serbia, the Porte had to concede to the Serbs the right for an internal administration "exempt from any external influence," leave them in possession of all the captured fortresses as well as renounce any plans for their resettlement. No Ottoman tax collectors or any other civil and military officials were supposed to enter Serbian territory. Instead, Serbian representatives were to deliver to Constantinople a moderate tribute, in the amount once and for ever established by the Ottoman, Russian and Serbian commissioners. Most importantly, the sultan would have to recognize Alexander I as "the guarantor of the exact implementation of these stipulations" "in consideration of the interest that the Russian emperor took in the fate and well-being of his Serbian coreligionists." 193

However, an impending war with France forced the Russians to scale down their demands with respect of the extent of Serbian autonomy. On the eve of the Russian- 
Ottoman peace negotiations in October 1811, Russian minister of foreign affairs N. P. Rumiantsev, instructed Kamenskii's successor, M. I. Kutuzov, to "secure the fate of Serbia as much in accordance with the desire of the Serbian nation as possible."194 Accordingly, Kutuzov envisioned the non-appointment of the Ottoman governors to Serbia and the right of the province to deliver the tribute through its deputies in Constantinople, yet he did not consider it feasible to make the Porte renounce its right to maintain a military garrison in Belgrade. ${ }^{195}$ There was similar softening of the demand to recognize Russia as a guarantor of the Serbian autonomy. Whereas in October 1811, Rumiantsev still insisted upon the inclusion of this clause into the treaty, ${ }^{196}$ by March 1812 Alexander I was ready to sign a separate Russian-Ottoman convention on Serbia at a later time if this could quicken the conclusion of peace. ${ }^{197}$

The softening of the Russian demands at least in part owed to the staunch resistance of the Ottoman representative Ghalib-Effendi to the idea of Serbian self-rule. From the very beginning of the discussions on Serbia in November 1811, Ghalib-Effendi was opposed to the inclusion into the peace treaty of any clauses that would limit the sultan's sovereignty over the province. ${ }^{198}$ Pressed to recognize Russia as a guarantor of Serbia's autonomy, the Porte's representative argued that the Serbs "had never had relations with other powers" and asserted the sultan's right to deal unilaterally with his subjects. At best, he was ready only to "promise to Russia the security and tranquility of [the Serbs]," in view of the fact that the latter "had made common cause with Russia during the present war." 199 In April 1812, Ghalib-Effendi rejected the idea of signing a separate Russian-Ottoman convention on Serbia at any time in future and reiterated the Porte's readiness to "promise to the Serbs security, bury the past and grant them pardon."200

The strong resistance of the Porte's representative made Kutuzov drop the demand for a Russian guarantee and accept the Ottoman draft of the article on Serbia. According to it, the Porte offered the general amnesty to the Serbs and, "moved by the sentiment of mercy," promised to "settle with the Serbian nation the security measures" necessary to protect them against vexations on the part of the Ottoman garrisons that were to reoccupy Belgrade and other fortresses. At the same time, Kutuzov managed to make Ghalib-Effendi concede to the Serbs "the organization of the islands [of the Archipelago] and some other territories in terms of internal administration and the mode of tax collection." ${ }^{201}$ In the end, the Porte had to offer to the Serbs "the same advantages that are enjoyed by the inhabitants of the Archipelago," leave to them "the administration of their internal affairs," accept the province's tribute from the hands of the Serbian deputies and arrange all these matters "in concert with the Serbian people." 202 
The resistance of the Ottomans effectively prevented Alexander I and his representatives from securing the same legal grounds for intervention into the Porte's relations with its Serbian subjects as Catherine II had earlier acquired with respect of Moldavia and Wallachia. However, the reference to "the privileges of the inhabitants of Archipelago," hereafter extended to Serbia, suggest that the stipulations of Kuchuk-Kainarji continued to determine the Russian approach to those Christian majority territories that had to return under the sultan's authority after the war. Unable to secure an explicit right "to speak in favor of" Serbia, Russian negotiators nevertheless managed to include in the peace treaty a number of stipulations that served the tsar's envoys to limit the Porte's authority over this province in the period that followed.

The peace of Bucharest disappointed the Serbian leaders just as the treaty of Kuchuk-Kainarji failed to meet the expectations of the Moldavian and Wallachian boyars. Nevertheless, the boyars had responded to the conclusion of peace in 1774 with the request that the Russian diplomacy "defend and support the rights of our country in accordance with the treaties" 203 and closely collaborated with the Russian envoys and consuls to that effect. By contrast, the Serbian leaders, unwilling to surrender the fortresses to the Ottoman garrisons and disarm themselves, initially pretended that the Bucharest peace did not contain any stipulations whatsoever concerning their land. Having fought the Ottomans for five years, the Serbs considered the captured fortresses as their main protection against janissary reprisals and accorded little value to the clause about "the privileges of the Archipelago islands," which could interest a less bellicose but more politically sophisticated elite.

As a result, in the first months after his return to Constantinople, the Russian envoy A. Ia. Italinskii found the Serbs and not the Porte to be the main obstacle to the implementation of the peace agreement. ${ }^{204}$ Indeed, the Ottomans explained their recourse to the repressive measures in June 1813 by the refusal of the Serbs to comply with the Russian-Ottoman treaty stipulations. In an attempt to prevent this, Italinskii tried to justify the Serbian refusal to disarm by reference to the "privileges of the Archipelago," now extended to Serbia, which included the right to bear arms. However, the Porte felt no obligation to observe the stipulations of the treaty that the Serbian leaders did not recognize and Italinskii's protests, unsupported by force, remained ineffective. ${ }^{205}$ As the Ottomans proceeded to brutally suppress the uprising, Karageorge requested the permission to resettle into Russia with the entire Serbian people of some 300,000 . However, the events quickly overtook this rather improbable project, which in the end boiled down to the emigration of the Serbian leader and some 40 loyal families to the Russian-controlled Bessarabia by way of Austria. ${ }^{206}$

The Carl Beck Papers in Russian and East European Studies http://carlbeckpapers.pitt.edu | DOI 10.5195/cbp.2015.201 | Number 2401 
For two years following the collapse of the uprising, Serbia was hardly on the agenda of the Russian diplomats pre-occupied with the negotiations of the post-Napoleonic settlement at Vienna, from which the Eastern question remained largely excluded. One Hundred Days prevented the Russian intervention on the Serbian question, prepared by the ascendant maker of Russia's Eastern policy I. A. Kapodistrias in response to the appeals brought to Vienna by the member of the first Serbian delegation to Alexander I, the archpriest Mateja Nenadović. In the meantime, the brutal regime established in Serbia by Suleiman-pasha, a native of Bosnia, provoked the second Serbian uprising under the leadership of Miloš Obrenović. Having scored a number of victories, Miloš successfully played off the Bosnians against the Porte and eventually secured the end of the reign of terror and his own appointment as a Serbian oberknez alongside a milder Ottoman governor.

In comparison to the regime of protectorate established over the principalities, Russian "protection" of Serbia during the 1810 s and 1820 s encountered considerable obstacles both on the level of the province and in the Ottoman capital. Moldavian and Wallachian boyar grievances, which the Russian consuls and envoys would relay to the Porte, were often aimed against the policies of the Phanariot princes and thus looked like petitions of some Christians against others. Although in 1808-1812, the Russians similarly supported the assembly of Serbian district leaders (knez) against the personal authority of Karageorge, their ability to play the "council" against the "prince" was severely limited in the following two decades by the absence of a Russian diplomatic agent in Belgrade. The presence of an Ottoman governor in Serbia after 1812 further complicated the reproduction of the Moldavian and Wallachian model: direct Russian championship of the "rights" of the land could easily be taken as an unacceptable challenge to the Muslim rule over Christians. Even more fundamentally, the Russian diplomats were perfectly aware of the fact that the Bucharest peace treaty did not grant them the formal right to continuously "speak in favor of" Serbia as was the case of the principalities. Neither Italinskii nor his successor G. A. Stroganov demanded to recognize Russia as the permanent formal guarantor of the Porte's prospective settlement with the Serbs and admitted that the Porte's refusal to make this settlement constituted the only basis of their interventions.

Nevertheless, by the late 1810 s, the efforts of the new Serbian leadership to expand and formalize their autonomy paralleled the struggle of the tsar's diplomacy to secure the fulfillment of the Russian-Ottoman treaties. Soon after his appointment in summer 1816, Stroganov reinterpreted Russia's right to demand the fulfillment of the Bucharest treaty as the right to mediate the Porte's settlement with Serbia and 
obtain written proofs of its implementation. He also demanded an imposition of "just taxation, an internal government of the knezes and primates in accordance with the laws and customs of the land, reduction of the Ottoman garrisons, admission of a Serbian representative to Constantinople and fixation of the payment of the Ottoman governor." ${ }^{207}$ The draft of the Russian-Ottoman convention that Stroganov wanted the Porte to sign also presupposed the appointment of a Russian representative to Belgrade who would overlook the fulfillment of the stipulations of the Bucharest treaty on Serbia. ${ }^{208}$ The formula of Serbia's autonomy and the proposed means to secure its implementation suggest that the tsarist diplomacy sought to redefine both Russia's relation to Serbia and the latter's status within the Ottoman Empire on the model of the Danubian principalities.

In parallel, Stroganov entered into secret correspondence with Miloš, who was eager to secure the Porte's formal recognition of both Serbia's autonomy and his own hereditary rule. ${ }^{209}$ This correspondence revealed the difficulty of establishing with the Serbian leadership the kind of cooperation that existed after 1774 between the tsars' diplomats and the boyars of Moldavia and Wallachia. Russian "representations" on the Serbian question were undermined by a letter of gratitude to the sultan that Miloš signed in 1817, on the suggestion of the Ottoman governor of Belgrade. In 1820, the Serbian delegation to Constantinople did not coordinate with the tsar's envoy a list of requests that they submitted the Porte. ${ }^{210}$ The Serbian leader asked Stroganov to prepare a project of petition about the rights of the Serbian people ${ }^{211}$ yet failed to provide the envoy with "detailed information... on all matters of internal administration, based on local customs and advantages of particular estates and the people in general." 212

Five years elapsed before Miloš began viewing the implementation of the Bucharest treaty as a means to achieve his goals and was ready to request that the Ottomans fulfill it. ${ }^{213}$ Once this happened, Stroganov suggested that in the definition of their demands to the Porte, the Serbs claim those rights of the Archipelago islands or Wallachia that would appear suitable to them. In particular, the envoy advised incorporating into their petition the Wallachian right to repair existing churches and build new ones. He also suggested claiming Wallachia's exemption from the passage of the Ottoman troops across the Serbian territory (apart from reduced garrisons in a few designated fortresses). Finally, in the demands of internal government, the Serbs had to take into consideration "the rights of all the Christian provinces rather than any particular one of them" in the view of the "differences in the geographical situation, mores, customs and existing institutions." 214 
The Greek Crisis of the 1820s ultimately helped to formalize both the autonomy of Serbia and the Russian protectorate over it. Although the disruption of the relations between the tsar and the sultan put the Serbian issue on hold for several years, the Porte's actions after March 1821 ultimately added to Russia's resolve to secure the implementation of the Bucharest treaty. Its stipulations with respect to Serbia were confirmed in the Convention of Akkerman of September 25, 1826 that established an eighteen-month deadline for the publication of the firman on the Serbian selfrule. ${ }^{215}$ Temporarily suspended by the Russian-Ottoman war of 1828-1829, the implementation of this settlement received further sanction in the treaty of Adrianople of September 2, 1829. ${ }^{216}$ Miloš's wise decision to stay neutral during both the Greek uprising of 1821 and the Russian-Ottoman war proved his loyalty to the Porte and further facilitated the Serbian cause. On October 17, 1830, Mahmud II signed the hatt-i sherif which confirmed Serbia's autonomy along the lines elaborated by Miloš and Stroganov in the late 1810s. ${ }^{217}$ Finally, the appointment of the Russian consul to Belgrade eight years later permitted St. Petersburg to exploit the tensions within the Serbian elite as it had done earlier in the principalities. ${ }^{218}$

Compared to the Russian-Romanian exchanges during and after the war of 1768-1774, the Russian-Serbian transactions in the first three decades of the nineteenth century appear to be quite similar. As was the case of the Romanian hospodars and boyars, the Serbian leaders appealed to St. Petersburg for protection and received reassuring messages from the Russian diplomats and commanders, who needed the support of coreligionists in the war against the Ottoman Empire. In both cases, the aspirations of Russia's coreligionists proved to be at least partly misplaced, when it became clear that their provinces would have to be returned to the Porte upon the conclusion of peace. In both cases, Russia tried to moderate the effect of dashed hopes of the Orthodox elites by introducing into the Russian-Ottoman treaties a number of provisions concerning autonomy of the territories in question.

At the same time, there were significant differences in the ways in which the political idiom of protection functioned with respect of Serbia and the Romanian principalities. In their appeals to the Russians, the Serbian leaders stressed common faith and blood, but lacked a developed notion of the "rights," "privileges," or "exemptions" specific to their land, such as had been developed by the Wallachian and Moldavian boyars. Although the principle of the Serbian self-rule found its way into the Russian-Ottoman peace treaty of Bucharest, it was not grounded upon any Ottoman "capitulations" similar to those that had supposedly conditioned the acceptance of the Ottoman sovereignty by the principalities. It shall be remembered that since the 1770 s these "capitulations" provided the ground for cooperation 
between the Russian diplomats on the one hand and the Moldavian and Wallachian boyars on the other, even though the two sides pursued divergent political agendas. By contrast, the failure of the Serbian leaders to develop their own theory of "capitulations" helps explain the lack of the Russian-Serbian cooperation in the immediate aftermath of the Bucharest treaty. References to "historical rights" of Serbia could have fleshed out the clause of the treaty with respect to the Serbian self-rule, which otherwise remained rather vague and therefore carried little weight in the eyes of the Serbian leadership or the Porte. For their part, the Russian diplomats remained deprived of solid pretexts for continuous interference into the OttomanSerbian relations in the decades that followed 1812. One can thus conclude that, despite linguistic proximity between the Serbs and the Russians, the language of protection functioned less smoothly in the Russian-Serbian-Ottoman relations than it had done in the relations between Russia, the Romanian principalities and the Porte.

\section{Conclusion}

The forgoing discussion demonstrates that in the half century following the Russian-Ottoman war of 1768-1774, Russian rulers positioned themselves as protectors of particular provinces of the Ottoman Empire with predominantly Orthodox populations and did this on the basis of the peace of Kuchuk-Kainarji and subsequent Russian-Ottoman treaties. In all the relevant cases, these agreements provided formal guarantees to the security of local Orthodox coreligionists following the occupation of the territories in question by Russian troops and/or military cooperation between the Russian army and the indigenous military formations. Depending upon the local situation, these guarantees took the form of stipulations in favor of the Orthodox Church and/or fixation of particular local "privileges" and internal autonomy. These treaty clauses proved to be particularly consequential for those provinces which had consolidated political elites. In such cases, cooperation between the Russian diplomats and these elites resulted in continuous remonstrations of the tsars' envoys to the Porte on behalf of the provinces in question. Over time, these remonstrations both widened the autonomy of the given provinces from the central Ottoman government and consolidated Russia's protectorate over them.

Moldavia and Wallachia were subject to Russian occupations more often than the other territories in question and therefore figured in all Russian-Ottoman treaties and major bilateral conventions concluded between 1774 and 1829 . The

The Carl Beck Papers in Russian and East European Studies

http://carlbeckpapers.pitt.edu | DOI 10.5195/cbp.2015.201 | Number 2401 
politically articulate boyars sought to secure themselves in conditions of repeated Russian-Ottoman wars by getting the two belligerent sides committed to respect the traditional rights and privileges of the principalities. As a result, the stipulations of the Russian-Ottoman treaties concerning Moldavia and Wallachia were the most elaborate, which gave the Russian protectorate over these provinces a solid foundation. Far from being Catherine's top priority in the early 1770s, Russia's formal prerogatives with respect to Moldavia and Wallachia became the most permanent factor of Russian-Ottoman relations between the peace of Kuchuk-Kainarji and the outbreak of the Crimean war. Rarely disputed by the Porte or other powers, these prerogatives served tsarist diplomats as a model of similar arrangements concerning Venetian Albania and Serbia, although none of these provinces remained under St. Petersburg's protectorate as long or as firmly as the principalities.

The demonstrated centrality of Moldavia and Wallachia to the Russian protectorate of coreligionists in the Ottoman Empire clarifies the origins and the general character of this phenomenon. The latter emerged in the context of Russia's repeated wars with the Ottoman Empire that tended to involve the Christian majority population in areas that constituted the battle theatre. As a discourse, protection of Orthodoxy served Russian rulers to enlist local support against the Ottomans. As a collection of treaty articles and diplomatic demarches, this protectorate served to minimize the negative political effects of repeated surrender of the territories in question to the Porte. It also made it possible for the tsars' ministers to interfere continuously in the relations between the sultans and their subjects in the outlying Christian provinces.

At the same time, the Orthodox community of the Ottoman Empire as a whole hardly figured in Russian-Ottoman relations in half a century following the conclusion of the landmark treaty of Kuchuk-Kainarji. Russia's liaisons with the official head of this community, the Ecumenical Patriarch of Constantinople, were at their all-time low during this period. At the beginning of each new Russian-Ottoman war, the current incumbent of this office duly admonished the Orthodox faithful to stay loyal to the Porte and "hate, chase away and fight those who are the enemies of our most powerful monarch." ${ }^{219}$ For its part, the Russian Holy Synod in this period did not exercise any active role in the affairs of Greek Orthodox Church in the realm of the sultan. Inasmuch as the high Orthodox clergy played a role in the crystallization of Russian protectorate over particular Christian majority provinces of the Ottoman Empire, this role belonged to the hierarchs of the territories in question and not to their superiors in Constantinople or their counterparts in St. Petersburg. Finally, the confessionally unspecific terminology of the Russian-Ottoman treaties suggests that, 
in their stipulations on behalf of coreligionists, the makers of Russia's Eastern policy did not feel the need to separate Orthodoxy from other Christian confessions. The use of the term "Christian" rather than "Orthodox religion" fitted well Catherine's original intent to present her coreligionists in Ottoman Empire as members of the universal Respublica Christiana. Her successors followed the same strategy until the mounting tensions between different Christian denominations in the decades following the Greek Crisis determined her grandson to become a guardian of the confessional frontiers of Orthodoxy.

This brings one to the more general conclusion about the place of Orthodoxy in Russia's foreign policy in the eighteenth and early nineteenth century. In the light of the present discussion, it becomes clear that the idea of Russia as the protector of the Orthodox coreligionists in the Ottoman Empire was not a Russian invention. As the Russian-Romanian relations since mid-seventeenth century demonstrate, the Orthodox coreligionists themselves suggested this idea to the Russian rulers and the better part of the eighteenth century elapsed before St. Petersburg began to apply this idea systematically in its relations with the Ottomans. Moreover, for forty years after the peace of Kuchuk-Kainarji, Russia hardly attempted to act as the protector of the entire Orthodox millet in the Ottoman Empire and limited its ambition to the championship of the rights of its coreligionists in particular Ottoman territories that returned under the Porte's control after a period of the Russian occupation.

It would thus be a mistake to follow a recent history of the Crimean War in seeing Russia's Eastern policy and Russia's relation to the world more broadly as being determined from the very beginning by a fundamentalist Orthodox outlook. ${ }^{220}$ Although the early sixteenth-century concept of "Moscow as the Third Rome" constituted an early expression of such outlook, its influence upon the tsarist diplomacy during the period under consideration is almost impossible to ascertain. The makers of Russia's foreign policy in the late 1700 s and early 1800 s were the representatives of westernized state-serving elite, to whom Wallachian and Moldavian boyars sometimes reminded of the defunct Byzantium or pre-Petrine Muscovy and who could perceive the Montenegrin and Serbian freedom-fighters as outright savages. ${ }^{221}$ As long as this cultural distance persisted, protection of coreligionists could only be an instrument of Russia's foreign policy and not its source; it thus constituted an aspect of raison d'état rather than a raison d'être. The situation changed only in the middle decades of the nineteenth century, when, in reaction to the revolutionary challenges, the same representatives of the westernized Russian elites reconceptualised Orthodoxy as one of the linchpins of the Russian society. In parallel, a series of ethno-confessional conflicts in the Ottoman Empire

The Carl Beck Papers in Russian and East European Studies http://carlbeckpapers.pitt.edu | DOI 10.5195/cbp.2015.201 | Number 2401 
made the tsarist diplomats and members of the Russian educated public increasingly preoccupied with the state and interests of the entire Orthodox community in the Christian East. This, however, takes one beyond the chronological scope of the present paper. 


\section{Endnotes}

1. Published in A. N. Petrov, Voina Rossii s Turtsiei i pol'skimi konfederatami, 1768-1774 (St. Petersburg: tip. Eduarda Veimera, 1866), 1:103-06. The manifesto was translated into Greek, Slavonic Serbian and "Wallachian." Contemporary Italian translation published in Storia della Guerra presenta tra la Russia, la Polonia e la Porta Ottomana (Venice: Graziosi, 1770), 5:90-95 and Documente privitoare la Istoria Românilor (București: Editura Socecu, 1876), 7:63-65. All dates are given according to the Julian calendar, which was used in Imperial Russia and which was twelve days behind the Georgian calendar in the eighteenth and nineteenth century.

2. H. B. Sumner, Peter the Great and the Ottoman Empire (Oxford, UK: B. Blackwell, 1949), 37-38; Brian L. Davis, Empire and Military Revolution in Eastern Europe: Russia's Turkish Wars of the Eighteenth Century (London; New York: Continuum, 2011), 159-63.

3. Published in Istoricheskie sviazi narodov SSSR i Rumynii (Moscow: Nauka, 1970), 3:331.

4. Catherine's ukaz to the Russian Senate concerning the dispatch of an agent with the task of announcing her "zeal and benevolence" towards the Christians of the European part of the Ottoman Empire. August 24, 1764, E. B. Smilianskaia, I. M. Smilianskiaia, M. B. Velizhev, Rossia v Sredizemnomorie: Arkhipelagskaia ekspeditsia Ekateriny II. Prilozhenie 1 (Moscow: Indrik, 2006), 493.

5. This discussion is based on Barbara Skinner, The Western Front of the Eastern Church: Uniate and Orthodox Conflict in $18^{\text {th }}$ Century Poland, Ukraine, Belarus and Russia (DeKalb, IL: Northern Illinois University Press, 2011), 88-134.

6. Supported by the Protestant Prussia and Great Britain, Russia faced the diplomatic hostility of both France and Austria as well as of Europe's smaller Catholic powers. Virginia H. Aksan, recently argued that one should not overestimate the role of France in the outbreak of the 1768-1774. See Virginia H. Aksan, Ottoman Wars, 1700-1870: An Empire Besieged (Harlow, UK: Pearson, 2007), 138-39. At the same time, the interest of France in the outbreak of this 
war is undeniable even if, admittedly, the Porte did not need the French counsel to recognize that its own strategic interests were threatened by continued Russian presence in Poland.

7. "Reskript ot 29 ianvara $1769 \mathrm{~g}$. vmesto polnoi mochi dlia peregovorov s grekami i slavianami," V. A. Ulianitskii, Dardanelly, Bosfor i Chernoie more $v$ XVIII v. (Moscow: A. Gatsuk, 1883).

8. Ibid.

9. "Manifesto on the Beginning of War with the Ottoman Empire," November 18, 1768, Polnoie sobranie zakonov Rossiiskoi Imperii, ser. 1, no. 13198 (St. Petersburg: Tipografia Vrotogo Otdeleinia Sobstvennoi E. I. Velichestva Kantseliarii). Hereafter cited as PSZ.

10. "Manifesto about the War Against the Ottoman Empire," September 7, 1787, PSZ, ser. 1, no. 16567, 22: 883-88.

11. "Manifesto on the Opening of War with the Ottoman Empire," April 14, 1828, PSZ, ser. 2, no. 1947, 3:383-84.

12. There was no manifesto at the outbreak of the war of 1806-1812, which the Porte declared after Alexander I ordered his troops to occupy of Moldavia and Wallachia in November 1806 in a rather self-defeating attempt to curtail the growing French influence in Constantinople. During the first six or seven months of hostilities, Russian diplomacy sought to mend the relations with the Porte and restore the pre-existing Russian-Ottoman alliance against the Napoleonic France.

13. For a general discussion of this approach, see Melvin Richter, "Reconstructing the History of Political Languages: Skinner, Pocock and Geschichtliche Grundbegriffe," History and Theory 29, no. 1 (1990): 38-70.

14. See the essays by Quentin Skinner in James Tully (ed.) Meaning and Context: Quentin Skinner and His Critics (Princeton, NY: Princeton University Press, 1988). See also J. G. A. Pocock, Politics, Language and Time: Essays on Political Thought and History (New York: Atheneum, 1971). 
15. From the sixteenth century onwards, the Ottoman documents would refer to the population of Moldavia and Wallachia as "protected" (zimmi) and to the Moldavian and Wallachian hospodars as "tribute-paying" (haraçgüzar). See Viorel Panaite, "The Re'ayas of the Tributary Protected Principalities: The Sixteenth Through the Eighteenth Centuries," International Journal of Turkish Studies 9, nos. 1-2 (2003): 86.

16. According to Peter Sugar, the Ottoman approach consisted in the creation of such buffers all along their frontier in Europe and only fierce Ottoman-Habsburg rivalry did not permit the application of the same principle to Hungary and necessitated the placement of the latter under the direct Ottoman rule (pashalyk). See Peter Sugar, South Eastern Europe under the Ottoman Rule 1354-1804 (Seattle and London: University of Washington Press, 1977), 70.

17. This bipartite division of the world characterized the approach of the Hanefi School of Islamic law that was adopted by the Ottomans in preference to three other major schools. See Tahsin Gemil, Romanians and Ottomans in the XIVth to XVIth Centuries (Bucharest: Romanian Academy, 2009), 23-30; According to Viorel Panatie, in the fourteenth and fifteenth century the principalities were viewed as part of "house of war," even though in the course of the 1400s they accepted to pay tribute to the sultans. Viorel Panaite, Pace, Război și Comerțt in Islam. Țările Române și Dreptul Otoman al Popoarelor (secolele XV-XVII) (București: B.I.C. ALL, 1997), 280-83.

18. Ibid., 410-13. The meaning of the tribute that the principalities paid to the Ottomans changed accordingly. If in the fifteenth century, the Ottomans viewed it as the payment for peace, in the sixteenth century they came to consider it as the sign of complete submission to the Porte. Viorel Panaite, "The voivodes of the Danubian principalities - as harâcgüzarlar of the Ottoman Empire," International Journal of Turkish Studies 9, nos. 1-2 (2003): 66, see also Gemil, Romanians and Ottomans, 30-50.

19. According to Panaite, over the 1400 s, 1500 s and 1600 s, the principalities de facto left the "house of war," but did not enter the house of Islam." Their juridical status should best be described in terms of "house of armistice" (dar al muvada'a) and "house of protection or tribute" (dar al dhimma), which where 
the closest Hanefi approximations to notion of "house of ageement or treaty" (dar al ahd) that existed in the Shafii school of Islamic law. Panaite, Pace, Război și Comerț in Islam, 421.

20. Ibid., 414-15.

21. For the definition of the duties of the Moldavian and Wallachian princes from the Ottoman perspective, see Panaite, "The Voivodes of the Danubian principalities - as Harâcgüzarlar of the Ottoman Empire," 59-61. For the use of the boyar reclamations by the Porte against the hospodars, see Tahsin Gemil, Relațiile Țărilor române cu Poarta otomană în documente turcești (1601-1712) (București: Direcția Generala a Arhivelor Statului din Republica Socialistă România, 1984), 14.

22. Dimitrie G. Ionescu, "Tratatul lui Gheorghe Ștefan cu Ruşii,” Revista istorică romînă 3, no. 2-3 (1933): 241-46; D. M. Dragnev, Ocherki vneshnepoliticheskoi istorii moldavskogo kniazhestva (posledniia tret'XIV - nachalo XIX v.) (Kishinev: Shtiintsa, 1987), 218-19. For the political infighting in Moldavia that led Gheorghe Ștefan turn to Moscow, see Tahsin Gemil, Țările române în contextul politic internațional (1621-1672), (București: Editura Academiei Republicii Socialiste România, 1979), 153-154.

23. Dragnev ed., Ocherki, 219-20.

24. See the corresponding imperial rescript in PSZ, ser. 1, vol. 2, 964-65.

25. Dragnev ed., Ocherki 234.

26. For Moscow's response to Cantacuzino's request, see PSZ, ser. 1, 2: 959-62.

27. The hospodars who approached the tsar were Constantin Brâncoveanu (1690, 1698) in Wallachia and Antioh Cantemir (1699), Constantin Duca (1701) and Mihai Racoviță (1704) in Moldova. See Istoricheskie sviazi narodov SSSR i Rumynii, vol. 3, 114-18, 132-35, 166 and 204-206 respectively. On Peter's relations with the hospodars prior to 1711, see Dragnev, ed., Ocherki, 24042 and G. S. Ardeleanu, "Știri din correspondența lui Petru I," Studii și cercetări 
de istorie medie, no. 1 (1950): 192-208. On the Lutsk treaty of April 1711 between Peter the Great and Dmitrie Cantemir, see Ion Focșeneanu, "Tratatul de la Luțk și Campania Țarului Petru I în Moldova (1711)," Studii privind relațiile romîno-ruse (București: Academia Republicii Populare Romîne, 1963), 1-55; Ion Eremia, "Considerații privid tratatul moldo-rus de la 1711," in Frontierile Spațiului Românesc în Contextul European (Chișinău: Editura Cartdidact, 2008), 102-20.

28. See the "articles" submitted by the Moldavian metropolitan Gedeon and logothete Necul on 12 May 1656, which stipulated that the Moldavian hospodar "remain in the same rank" as his predecessors prior to the Ottoman vassalage and that his "honor and rank do not get ruined... as it was not ruined by the godless ones." The articles were confirmed by the tsar on 20 May 1656, after which the Moldavian representatives swore the oath of loyalty to the tsar. See PSZ, ser. 1, 2:385-90. The Romanian term raia (pl. raiale) derived from the Ottoman Turkish reaya, which originally designated non-military tax-paying population of the Ottoman Empire as distinct from its military class (askeri or kul). Halil Inalcik with Donald Quataert (eds.), An Economic and Social History of the Ottoman Empire (Cambridge, UK: Cambridge University Press, 1997), 1:16-17. However, in the Danubian principalities, this term came to be applied to territories that had been exempted from the jurisdiction of the Moldavian and Wallachian princes and subordinated to the governors of the Ottoman fortresses Turnu, Giurgiu, Brăila, Reni and Ismail on the Danube and Bender and Hotin on the Dniester. The population of these territories had to sustain the Ottoman garrisons. This usage implied that, although Moldavia and Wallachia paid tribute to the Ottomans and had their rulers appointed by the Porte, their population outside the raiale districts were not reayas as were their coreligionists south of the Danube who lived under the direct rule of the Ottoman pashas. However, the Ottoman documents would still apply the term reaya to the Moldavians and Wallachians, calling them "tribute-paying" (rather than tax-paying) reaya (haraçgüzar reaya). See Panaite, "The Re'ayas of the Tributary Protected Principalities," 84.

29. See "Stat'i prislannyie iz Varshavy k tsariu Alexeiu Mikhalovichu ot volokhskikh boyar Radula i Petrashki na kakikh usloviakh zhelaiut oni byt' v rossiiskom poddanstve," PSZ, ser. 1, 971-72. 
30. Diplom, dannyi valakhskomu kniaziu Dmitriiu Kantemiru," PSZ, ser. 1, 4: 659-61.

31. With the exception of the prince of Moldavia Alexander Mavrocordat Firaris (the Fugitive), who in 1787 defected to the Russians, the only hospodar to accept Russian suzerainty in the post-1711 period was the Wallachian prince Constantine Ypsilanti. The prince did so at the outbreak of the Russian-Ottoman war of 1806-1812 in the expectation to establish the dynastic rule of the Ypsilantis over both principalities. See George F. Jewsbury, Russian Annexation of Bessarbia, 1774-1828: A Study of Imperial Expansion (Boulder, Colo.: East European Monographs, 1975), 37-43. Vladimir Mischevca and Periklis Zavitsanos, Principele Constantin Ypsilanti (Chişinău: Civitas, 1999).

32. The Phanariot rule in Moldavia and Wallachia is a controversial subject in Romanian historiography. The nineteenth-century critical evaluations of the Phanariots by Mihai Kogălniceanu L'Istoire de la Dacie, des Valaques Trasdanubiennes et de la Valachie (Berlin: Librairie B. Behr, 1854), 372, and A. D. Xenopol, Epoca Fanarioților pâna la 1812 (Iaşi: Editura librăriei şcoalelor fraţii Saraga, 1896), gave way to more positive appraisals by Nicolae Iorga, Byzance après Byzance (Bucarest: L'Institut d'Etudes Byzantines, 1935), or Florin Constantiniu and Șerban Papacostea, "Les réformes des premiers princes phanariotes en Moldavie et en Valachie: Essai d'interpretation," Balkan Studies 13, no. 1 (1972): 89-118. For a recent discussion of the role of the Phanariots in the Ottoman governance, see Christine M. Philliou, Biography of an Empire: Governing the Ottomans in an Age of Revolution (Berkley, CA: University of California Press, 2011), 5-37.

33. E. B. Shul'man, "Prorusskaia partia v Valakhii i ee sviazi s Rossiei. 17361737," in Russko-rumynskie i rumynsko-russkie otnoshenia (Kishinau: Shtiintsa, 1969), 7-41.

34. Cited in L. E. Semenova, Kniazhestva Moldavia i Valakhia, konets XIVnachalo XIX vv. Ocherki vneshnepoliticheskoi istorii (Moscow: Indrik, 2006), 316. On Drăgunescu's mission, see E. B. Shul'man, "Missia valashskogo vornika P. Drăgunescu v Rossiiu (1736-1737 gg.)," in Vekovaia druzhba (Kishinev: Shtiintsa, 1963), 211-39; Dragnev, ed., Ocherki, 262. 
35. In 1718-1739, the Habsburgs controlled the westernmost part of Wallachia (Oltenia). See Şerban Papacostea, Oltenia sub stapânirea austriaca, 1718-1739 (București: Editura Enciclopedică, 1998).

36. “Gramota valashskikh boyar imperiatritse Anne Ioannovne," April 26, 1737, published in V. N. Vinogradov, L. E. Semenova, "Nekotorye voprosy otnoshenii mezhdu Rossiiei i Dunaiskimi kniazhestvami v XVIII - nachale XIX veka v svete materialov sovetskikh arkhivov," in Balkanskie narody i evropeiskie pravitel'stva, ed. G. L. Arsh (Moscow: Nauka, 1982), 19-22.

37. See D. F. Maslovskii, Stavuchanskii pokhod. Dokumenty 1739 g. (St. Petersburg: Voenno-uchebnyi komitet Glavnogo Shtaba, 1892), 187-88; Dragnev, Ocherki, 271-73.

38. Ca. 4000 Moldavians followed Dimitrie Cantemir into his Russian exile, including his suite, some boyars and part of those troops that the hospodar assembled in support of the tsar (although the majority of them returned to Moldavia several years later). Cantemir's suite included the ancestors of Mikhail Kheraskov, Nikolai Bantysh-Kamenskii and Ilya Mechnikov. During the eighteenth -early nineteenth century no fewer than 13 representatives of the Cantacuzino family entered the Russian service. After the conclusion of the Iași peace treaty in 1792, some representatives of the boyar families of Sturdza, Bals, Rossetti and Ghica moved to Russia. See, M. Cazacu, "Familles de la noblesse roumaine au service de la Russie, XVe - XIXe siècle," Cahiers du monde russe et sovietique 34, nos. 1-2 (1993): 211-226. Although all Russian-Ottoman treaties starting from Belgrade (1739) contained a clause on the non-punishment of "the subjects of both empires which in the course of war defected to the opposite side," there was little or no practical possibility to enforce this clause. The emigration of the Romanian nobility to Russia was part of the broader process of migration of ethnic Romanians of all social classes into Southern Russia during the eighteenth century. See A. Vianu, "Cîteva date privitoare la emigrarea romînilor în sudul Rusiei în secolul al XVIII-lea," Studii privind relațiile romîno-ruse (București: Academia Republicii Populare Romîne, 1963), $57-65$.

39. A descendant of Bulgarian émigrés to Russia, N. A. Karazin was charged 
with the task of sounding the attitudes of the Christian population of Moldavia, Wallachia and the Ottoman territories to the south of the Danube. Dressed as a pilgrim, the emissary of the empress twice crossed the Danube in 1768-1769 and, on the second occasion, managed to penetrate as far as Adrianople collecting the military intelligence along the way. O. V. Medvedeva, "Bolgary," in Vek Ekateriny II. Dela Balkanskie, ed. by V. N. Vinogradov (Moscow: Nauka, 2000), $147-48$.

40. See Catherine's letter of Cantacuzino on January 19, 1769, Ulianitskii, Dardanelly, cii. According to one document, high Wallachian clergymen appealed to Catherine II for protection as early as January 1769 , ten months before the Russian occupation of Bucharest. See "Scrisoare archiereilor către augusta Impărăteasă," Nicolae Iorga, ed., Genealogia Cantacuzinelor de banul Mihai Cantacuzino (București: Institutul de Arte Grafice și Editură Minerva, 1902), 439-41.

41. For Cantacuzino's correspondence with the Russian commanders-in-chief A. M. Golitsyn, his successor P. A. Rumiantsev and general Ch. F. von Stoffeln, see ibid., 428-39, 441-47. Upon his return from Adrianople, Karazin gathered a detachment of local mercenaries (arnauți) and managed, with Cantacuzino's help, to occupy the Wallachian capital in November 1769, before the arrival of the regular Russian troops.

42. Wallachians to Catherine II, November 28, 1769, Vinogradov, Semenova, "Nekotorye voprosy," 27.

43. They were so enthusiastic that the lieutenant-general J. K. von Elmpt, who administered their oath at the Iași cathedral in late September 1769, had to call in some troops "for the maintenance of order." J. K. von Elmpt to P. A. Rumiantsev, September 26, 1769, P. K. Fortunatov, ed., P. A. Rumiantsev. Sbornik dokumentov $i$ materialov (Moscow: Voiennoie izdatel'stvo ministerstva oborny SSSR, 1953), 2:148.

44. For the Ottoman manifesto, see Petrov, Voina Rossii s Turtsiei, 1:278-79. For Rumiantsev's manifesto to Moldavians of October 31, 1769, see Fortunatov, P. A. Rumiantsev. Sbornik, 174-75. 
45. "Gramota Moldavskh boiar i dukhovenstva na imia Ekateriny II," December 10, 1769, Vinogradov, L. E. Semenova, "Nekotorye voprosy," 36, also published in V. N. Vinogradov, ed., Bessarabia na perekrestke evropeiskoi diplomatii (Moscow: Indrik, 1996), 64-65.

46. Cited in E. I. Druzhinina, Kuchuk-Kainardzhiiskii mir1774 goda (Moscow: Akademia Nauk SSSR, 1955), 122.

47. See the list of questions of P. A. Rumiantsev to the members of the Wallachian delegation to Catherine II and their answers in Iorga, ed., Genealogia Cantacuzinelor, 456-57..

48. See the Wallachian address to Catherine, published in V. A. Ulianitskii, Dardanelly, ciii-civ. "Rech moldavskikh deputatov na audientsii Ekateriny II," March 28, 1770, Vinogradov (ed.) Bessarabia, 65.

49. V. A. Ulianitskii, Dardanelly, cv. Catherine's response followed closely the formulas suggested by the members of the Wallachian deputation. See "Rugăciunea îndreptată Contelui Panin ca să facă manifestul precum mai jos se vede," Iorga (ed.) Genealogia Cantacuzinelor, 479-81. The full text of Catherine's reply to the Moldavian deputation is published in Vinogradov (ed.) Bessarabia, 66-67.

50. The first version of Russian peace proposals formulated in December 1770 still included the demand of the independence of the principalities. See "Plan sur laquelle Sa Majesté l'Impératrice de Russie se propose de négocier sa paix avec la Porte Ottomane," December 1770, Johann Eustachius Görtz, ed., Mémoires et actes relatives aux négociations qui ont précédé le partage de la Pologne (Paris: s. n., 1810), 125.

51. Catherine to Panin, not dated, Chteniav Obshchestve Istorii i Drevnostei Rossiiskikh, no. 2 (1863): 113. Further cited as ChOIDR.

52. See "Ce răspunsurile am făcut la întrebările ce ni-a făcut Contele Panin despre starea ținuturilor," and "Întrebările ce a făcut contele Panin deputaţilor și răspunsurile acestora," Iorga, ed., Genealogia Cantacuzinelor, 460-65 and 
468-81. In parallel, the boyars provided Procurator General of the Russian Senate A. A. Viazemskii with a description of how particular Phanariot princes increased particular taxes in violation of the customs of the land. See "Răspunsurile ce am dat noi scris cneazului Vezemschi," Ibid., 481-484.

53. Catherine to A. G. Orlov, March 22, 1771, Sbornik Imperatorskogo Russkogo Istoricheskogo Obshchestva, vol. 97, 252-253; N. I. Panin to A. G. Orlov, November 12, 1771, Russkii Arkhiv, kn. 3 (1880): 240.

54. Catherine to A. G. Orlov, March 22, 1771, SIRIO, vol. 97, 253, adopting the proposal that Panin made at the sessions of the State Council on September 16, 1770 and March 14, 1771, Arkhiv gosudarstvennogo soveta (St. Petersburg: Tipografia Vtorogo Otdelenia Sobstvennoi E. I. V. Kantseliarii, 18690-1904), $1: 60,371$.

55. See their letter to Orlov of August 6, 1772, Iorga (ed.), Genealogia Cantacuzinelor, 492-95.

56. “O deosebită propunere către domnul Obrescov," not dated, apparently submitted in January 1773, Ibid., 512-514. In parallel, the boyars asked Austrian envoy, to use all his influence "in order to keep us in our ancient rights." See Ibid., 487-490.

57. Most specialists on the subject of capitulations indicate that these texts were presented by Mihai Canatacuzino to Count Grigorii Orlov during the congress of Focșani in August 1772. See "Actele ce s-au dat contelui Orlof la Congresul din Focşani, August 30, 1772,” Ibid., 495-508.

58. The issue of the Ottoman "capitulations" to the principalities generated a voluminous literature and an unending historiographical debate. The Romanian historians of the twentieth century demonstrated that the texts of capitulations published by their nineteenth-century predecessors were in fact late eighteenthcentury forgeries (the earliest extant copy is dated by 1804). Iorga, ed., Genealogia Cantacuzinelor, 68, Constantin Giurescu, Capitulațiile Moldovei cu Poarta Ottomană (București: Institutul de Arte Grafice Carol Göbl, 1908), passim. See also Vlad Georgescu, ed., Mémoires et projets de reformes dans les 
principautés Roumaines, 1769-1830 (Bucarest: Association international d'études du Sud-Est Européen, 1970), 6-7. There were multiple editions of the texts of the "capitulations" during the $19^{\text {th }}$ century. See, for example, Mihai Mitilineu, ed., Colecțiune de tratatele și convențiunile ale României cu puterile straine (București: Noua tipografia ale laboratorilor români, 1874), 6, 18, 35, 51. For the French translation of the first two treaties see Felix Colson, De l'Etat present et de l'avenir de principautés de Moldavie et de Valachie (Paris: A. Pougin, 1839), 323-25. The predominant opinion of the present day Romanian historiography is that, although forgeries, the "capitulations" were predated by the actual Ottoman ahd-names and hatt-i sherifs issued by the sultans to the hospodars in the fifteenth and early sixteenth century, the copies of which were later lost. See Panaite, Pace, Război și Comerț în Islam, 322-25. However, the texts of these original hatt-i sherifs and ahd-names still remain to be discovered in the Ottoman archives. For an overview of the historiography of "capitulations," see Mihai Maxim, Țările Române și Înaltă Poarta (București: Editura Enciclopedică, 1993), 21-55; Semenova, Kniazhestvo Moldavia i Valakhia, 21-31.

59. Iorga, ed., Genealogia Cantacuzinelor, 496-97.

60. Ibid., 498-99.

61. “Stricăciunea privilegiilor și ruinarea a Țerii Românești, ” Ibid., 500-505.

62. Constantin Giurescu, Capitulațiile Moldovei, 6-11.

63. The spurious character of the story of Bogdan's "inclination" of Moldavia and subsequent developments is evident from multiple historical errors contained in the memoir, which suggest the influence of Dmitrie Cantemir's The History of the Growth and Decay of the Othman Empire, transl. N. Tindal, 2 vols. (London: James, John, and Paul Knapton, 1734-35), republished in French and German translations in 1743 and 1744 respectively, as well as his Descriptio Moldaviae (first published in German in 1769-1771). See Giurescu, Capitulațiile, 16-21.

64. Metropolitan Gedeon to P. A. Rumiantsev, not dated, Petrov, Voina Rossii s Turtsiei i pol'skimi konfederatami, 1768-1774, 4:138. 
65. See their message to Obreskov of January 3, 1773, Iorga, ed., Genealogia Cantacuzinelor, 508-12.

66. As reported in Obreskov to Panin, January 19, 1773, cited in Druzhinia, Kuchuk-Kainardzhiiskii mir, 237.

67. Obreskov to Abdur-Rezak, February 4, 1773, Ulianitskii, Dardanelly, ccxliccxliii.

68. See $\S \S 4$ and 2 of art. 20 of Obreskov's peace project published in Druzhinina, Kuchuk-Kainardzhiiiskii mir, 345, that became $\S \S 4$ and 2 of the art. 16 of the Kuchuk-Kainarji treaty, T. P. Iuzefovich, ed., Dogovory Rossii s Vostokom (St. Petersburg: tip. O. I. Baksta, 1869), 32-33 (Another Russian edition of the treaty can be found in PSZ, ser. 1, no. 14164, 19:959-969). For an English translation made from a French translation of the Italian version of the treaty, see J. C. Hurewitz, ed., The Middle East and North Africa in World Politics: A Documentary Record (New Haven and London: Yale University Press, 1975), 1:92-101.

69. In line with the boyar representations, Obreskov also demanded that the Ottomans return to the monasteries and private persons the lands that the pashas of Brăila, Khotin and Bender had illegally alienated into the reayas. See Art 20 of Obreskov's peace project, Druzhinina, Kuchuk-Kainardzhiiskii mir, 345-346. Obreskov presented these conditions on the last conference of the Bucharest congress, on March 8, 1773, Ulianitskii, Dardanelly, cclvi-cclvii. Sixteen months later, all of these clauses found their way into the Kuchuk Kainarji treaty. Iuzefovich, ed., Dogovory, 32-34; Hurewitz, The Middle East, 1:97.

70. See $\S 11$ of art. 20 of Obreskov's peace project, ibid., 346, which became $\S$ 10 of art. 16 of the Kuchuk Kainarji treaty, Iuzefovich, ed., Dogovory, 34. Unlike the Italian version of the treaty signed by both the Russian and the Ottoman representatives, G. F. Martens, ed., Recueil des traités d'alliance (Gottingen: J.C. Dieterich, 1791), 2:304, 306), the Russian text of the treaty omitted the word "representations," which made it somewhat ungrammatical. See Iuzefovich, ed., Dogovory, 34. 
71. See their message to Catherine II of March 30, 1774, Iorga, ed., Genealogia Cantacuzinelor, 514-18. In their parallel letter to P. A. Rumiantsev, the boyars painted before the Russian commander the prospect of unification of the "famous Dacia" with the Russian Empire. They also proposed Rumiantsev the glorious epithet of "Dacic," still before Catherine granted him the title of RumiantsevZadunaiskii (the Trans-Danubian). Ibid, 519-21.

72. See the boyar message to Catherine of June 1774 as well as their letters to N. I. Panin, G. A. Potemkin, G. G. Orlov and Z. G. Chernyzhev, Ibid. 524-25, 529-32.

73. Boyars to Rumiantsev, June 13, 1774, Ibid., 532-35.

74. See $\S \S 8$ and 9 of the art. 20 of Obreskov's peace project, Druzhinina, Kuchuk-Kainardzhiiskii mir, 345. The former Russian envoy at the Porte must have found this formula of vassalage a useful way of implementing the guarantees of Moldavian and Wallachian rights and privileges that Catherine had given to the deputies of the principalities in 1770 .

75. Boyars to Rumiantsev, June 13, 1774, Iorga, ed., Genealogia Cantacuzinelor, 534.

76. “Anaforaua Mitropolitului Țării și a celorlalți boieri pentru privileghii către contele Romanțov după închierea păcii,” July 10, 1774, Ibid., 537-540.

77. See "Alte trei ponturi adaogite în anaforele către Măria Sa Impărătească și către contele Panin date prin prinţul Potemkin,” Ibid., 540.

78. L. E. Semenova has pointed to the suspicious dating of Cantacuzino's exposé, the absence of these documents in the Russian archives, the absence of any references to them during the negotiations at Focşani and Bucharest as well as the difference between Cantacuzino's version of Wallachian "rights and privileges" and the one contained in Obreskov's peace proposal and the final text of the treaty. On the other hand, Semenova pointed to the similarity between Cantacuzino's exposé and the description of privileges that the Wallachian boyars submitted to Rumiantsev after they learned about the treaty's reference 
to "the rights that the principalities enjoyed at the time of Mehmed IV." These observations served Semenova to argue that Cantacuzino invented the Wallachian "capitulations" after the conclusion of the peace treaty, in Russian emigration, with the possible goal of inflating the role of the Wallachian delegation in the peace talks. Semenova, Kniazhestva Moldavia i Valakhia, 40-41, 44-46, 52.

79. Once again, Semenova challenged the earlier historiography and, in particular, Constantin Giurescu who dated the description of the Moldavian "capitulations" by the period of the congress of Focșani. Giurescu, Capitulațiile Moldovei, 21-33. In particular, Semenova noted that the original hatt-i sherif to Bogdan III that figured in this description was not mentioned in the "History of Moldavia" composed for the reference of the Russian diplomatic representatives at the negotiations of 1772-1773. According to Semenova, the description was composed in 1775, at the request of the Russian Extraordinary Envoy to the Porte N. V. Repnin, who promised to the Moldavian boyars to intervene on behalf of the principality. Semenova, Kniazhestva Moldavia i Valakhia, 48.

80. See art. 7 of the convention of Anaily-Kavak, PSZ, ser. 1, no. 14851, 20:804 (Other edition: Gabriel Effendi Nouradounghian, ed., Recueil d'actes internationaux de l'Empire Ottoman (Paris: Librairie Cotillon, 1897, 1: 343). See arts. 4 and 5 of the treaties of Iași and Bucharest respectively. Iuzefovich, ed., Dogovory, 43-44, 51-52.

81. For the hatt-i sherifs of 1775 to the hospodar Grigore Ghica (in Moldavia) and Alexander Ypsilanti (in Wallachia), see ChOIDR, kn. 1, part. 2 (1886): 52-61.

82. On the establishment of the Russian consuls in Moldavia and Wallachia, see B. G. Spiridonakis, "Le Consulat Russe dans les principautés Danubiennes," Balkan Studies 4 (1963): 289-314. D. Dvoichenko-Markov, "Russia and the First Accredited Diplomat in the Danubian Principalities," Slavic and East European Studies 8 (1963): 200-229. G. S. Grosul, Dunaiskie kniazhestva v politike Rossii, 1774-1806 (KIshinev: Shtiintsa, 1975).

83. Although the representatives of other European governments appeared in Moldavia and Wallachia soon thereafter, the Russian consuls for a long time remained unparalleled in the extent of their treaty-based local political influence. 
84. See instructions to Lashkarev cited in A. A. Giers, "Iz proshlogo konsul'stva v Iassakh," Russkaia starina 89 (1893): 317. See also the instructions of the College of Foreign Affairs to I. I. Severin, April 15, 1792, and the Russian charge d'affaires in Constantinople A. Khvostov to Severin, November 1, 1792, Vinogradov, ed., Bessarabia, 81-84.

85. See the reports of Severin of February 24, 1784, April 10, 1785, November 9, 1786, May 5, 1787 and September 12, 1794, Ibid., 77-79, 86.

86. For an example of such complaints, see "Obraschenie Moldavskikh boiar ot imeni zhetelei vsego kniazhestva v rossiskoie konsul'stvo," March 10, 1799, Ibid., 87-89.

87. For post-war tax exemptions, see $\S 7$ of art. 16 of Kuchuk-Kainarji treaty, $\S 3$ of art. 4 of the treaty of Iași and art. 5, of the treaty of Bucharest, Iuzefovich, ed., Dogovory, 33, 44 and 52 respectively. For an example of the boyar complaints about the Phanariots predatory exactions, see "Obraschenie Moldavskikh boiar," Vinogradov, ed., Bessarabia, 87-89.

88. The restitution of these lands was stipulated in the treaty of Kuchuk-Kainarji ( 33 of art. 16) and the convention of Ainaly-Kavak ( $\$ 2$ of art. 7). See Iuzefovich (ed.), Dogovory, 33, and Nouradounghian, Recueil, 1:343, respectively.

89. See $\S 8$ of art. 16 , Iuzefovich, 33 , confirmed by $\S 4$ of art. 7 of the “Convention explicative," PSZ, ser. 1, no. 14851, 20:804, and the hatt-i sherifs of 1784. Martens, ed., Recueil des principaux traites d'alliance, 3: 281-292.

90. "Obrashchenie moldavskikh boiar i dukhovnykh chinov k Aleksandru I," no later than January 24, 1802, Vinogradov, ed., Bessarabia, 97. Complaints of the hospodars and the boyars about the raids of the Tatars and the Ottoman governors of the neighboring provinces were quite frequent in the early modern period, yet prior to the peace of Kuchuk-Kainarji they were addressed to the sultan, who would issue prohibitions to his vassals and governors to plunder to plunder the reayas who are loyally paying the tribute. See Panaite, "The Re'ayas of the Tributary Protected Principalities," 87-90. 
91. The hatt-i sherif $s$ of 1802 fixed the seven-year term of appointment for the hospodars and made their deposition prior to the expiration of that term conditional upon Russia’s consent. See Grosul, Dunaiskie kniazhestva, 154-65.

92. See V. Ia. Grosul, Reformy v Dunaiskikh kniazhestvakh 20-kh-30-kh gg. XIX veka i Rossia (Moscow: Nauka, 1966); Victor Taki, "Russia on the Danube: Imperial Expansion and Political Reform in Moldavia and Wallachia, 18121834." PhD. Thesis, Central European University, 2007.

93. Ariadna Camariano-Cioran, "La Guerre Russo-Turque de 1768-1774 et le Grecs," Revue des Etudes Est-Européenes 3, nos. 3-4 (1965): 513-547 ; Smilianskaia et al, eds., Rossia v Sredizemnomorie, 38-55.

94. See L. G. Arsh, "Rossiiskie emissary v Peloponese i Arkhipelagaskaia ekspeditisa 1770-1774," Novaia i novshaia istoria, no. 6 (2010): 61-62. Another Russian emissary to Greece in this period was George Papazolis, an native of Macedonia and an artillery captain in Russian service. With the help of a Morean expatriate to Corfu Ivan Palatino, Papazolis contacted the most important clergymen and lay leaders in Morea, including Panaiotis Benakis, whose family played an active pro-Russian role in 1768-1774 and subsequently entered into the Russian service. On the activities of Papazolis, Palatino and Saros, see Smilianskaia et al., Rossia v Sredizemnomorie, 38-55.

95. For Levashev's report, see Druzhinina, Kuchuk-Kajnardzhiiskii mir, 103. For Tomara's "Memorandum on the Greeks," see Arsh, "Rossiiskie emissary," 65-66.

96. See the protocol of the session of the State Council of November 12, 1768, Arkhiv Gosudarstvennogo Soveta, 1:10.

97. Presented at the session of the State Council on November 27, 1768, Ibid., $1: 13$.

98. "Message of Peter the Great to the Montenegrin people with a call for an anti-Ottoman uprising," A. L. Narochnitskii, N. Petrović, eds., Politicheskie $i$ kul'turnye otnoshenia Rossii s iugoslavianskimi zemliami v XVIII v. Dokumenty (Moscow: Nauka, 1984), 29-30. 
99. Danilo Petrović was the first to visit Russia in 1715 , followed by his successors Vasile Petrović and Sava Petrović in 1742, 1753-1759 and 1766. Russian emissaries to Montenegro included Mikhail Miloradovich and Ivan Lukashich in 1711, councillor S. Puchkov in 1758-1760, sub-lieutenant Mikhailo Tarasov in 1766 and prince Iu. V. Dolgorukov in 1769. See N. I. Khitrova, "Russko-chernogorskie sviazi v XVIII v. (tserkovnye i kul'turnye)," in XVIII vek: Slavianskie i Balkanskie narody i Rossia, ed. by I. I. Leshchilovskaia (Moscow: Institut slavianovedenia i balkanistiki RAN, 1998), 6-26.

100. Thus, councillor Puchkov, dispatched to pacify the quarrelling Montenegrin factions, reported to Empress Elizabeth that "no use can be expected from Montenegro, as this people do not care to serve your Imperial Majesty and apparently all matter of advice on the creation of a Senate and a corps will turn into nothing." Cited in A. P. Bazhova, Russko-iugoslavianskie otnoshenia vo vtoroi polovine XVIII v. (Moscow: Nauka, 1982), 82. Iu. V. Dolgorukov, who came to Montenegro in order mobilize its inhabitants for an anti-Ottoman struggle in 1769, argued that the Montenegrins "live by theft, robbery and banditry with no regard to faith, friendship or humanity." See "Zhurnal'naia zapiska proisshestviam vo vremia ekspeditsii ego siatel'stva kniaza Iuria Vladimirovicha Dolgorukogo v Chernuiu Goru," Russkii arkhiv, no. 4, book 1 (1886): 408.

101. M. M. Freidenberg, "Stepan Malyi iz Chernogorii," Voprosy istorii, no. 10 (1975): 118-132.

102. As has been mentioned, M. Ia. Ezdemirovich and Efim Belich brought Catherine's anti-Ottoman manifesto to Montenegro. Iu. V. Dolgorukii's mission to Montenegro of the same year was a failure.

103. Proshenie grecheskogo naroda na imia Ekateriny II, January 6, 1769, SIRIO, vol. 2, 284-85.

104. Cited in Arsh, "Rossiiskie emissary v Peloponese, " 62.

105. As reported by the British ambassador in St. Petersburg, Lord Cathcart to the Earl of Rochford, on August 13/24, 1769, SIRIO, vol. 12, 461-463. 
106. A. G. Orlov to Catherine, not dated, apparently written in the fall 1768, A. N. Kashpirev, ed., Pamiatniki novoi russkoi istorii, vol. 1 (St. Petersburg: A. F. Bazunov, 1871), 142-43.

107. Catherine II to A. G. Orlov, January 29, 1769, SIRIO, vol. 1,2.

108. On the propaganda aspect of the Archipelago expedition, see Smilianskaia et. al., Rossia v sredizemnomorie, 413-33.

109. Catherine to A. G. Orlov, July 19, 1770, SIRIO, vol. 1, 41-42.

110. See Camariano-Cioran, "La Guerre Russo-Turque," 526; Smilianskaia et. al., Rossia v sredizemnomorie, 74-79, 114-29.

111. Ibid., 526, note 57.

112. Catherine to Orlov, September 3, 1770, SIRIO, vol. 1, 51.

113. Catherine to Orlov, January 29, 1769, SIRIO, vol. 1, 10.

114. Minutes of State Council, September 16, 1770, Arkhiv Gosudarstvennogo Soveta, 1:60

115. Published in Görtz, ed., Mémoires, 123.

116. Catherine II to A. G. Orlov, March 22, 1771, SIRIO, vol. 97, 248.

117. "A Summary Account of the Transactions of the Russian Fleet from the Time of their Arrival on the Coast of Greece in March 1770 to the Battle of Chesma on the coast of Natolia on the $5^{\text {th }}$ of July Following," SIRIO, vol. 19, 8889. The region of Sphakia on the Crete indeed revolted under the leadership of Dascaloiannis at the news of the arrival of the Russian fleet to Morea. However, Orlov never came help the Cretan rebels apparently under the influence of the defeat in Morea. Camariano-Cioran, "La Guerre Russo-Turque," 527.

118. European consuls to A. G. Orlov, July 21, 1770, published in Smilianskaia 
et. al., Rossia v sredizemnomorie, 602-603.

119. Ibid.

120. Seid Hasan to Orlov, July 21, 1770, Ibid., 604.

121. In order to achieve this goal Catherine needed Russia's definitive acquisition of Kabarda in the Caucasus, its unconditional sovereignty in the Azov district (that remained demilitarized since 1739) as well as the independence of the Crimea. See Catherine II to Orlov, March 22, 1771, SIRIO, vol. 97, 248-51.

122. See the protocol of the session of the State Council of March 12, 1771, Arkhiv gosudarstvennogo soveta. 1: 370 .

123. Catherine II to N. I. Panin, not dated, early 1771, ChOIDR, no. 2 (1863): 113.

124. At the outbreak of the war, Patriarch Meletius II (1765-1769) was suspected of disloyalty, deposed and exiled to Tenedos. His successor Theodosius II (17691773) could ill afford not to be a loyal instrument of the Porte. Ivan Sokolov, The Church of Constantinople in the Nineteenth century. An Essay in Historical Research. Translated from the Russian by Hieromonk Nikolai Sakharov (Oxford: Peter Lang, 2013), 121.

125. Smilianskaia et. al., Rossia v sredizemnomorie, 149-151. Their address to Catherine II of February 13, 1771 is published in Ibid., 605. Although a number of the local Orthodox hierarchs thereby definitively cast their lot with the Russians, the Ecumenical Patriarch Theodosius II, according to Orlov, "would issue secrete admonitions [to the Archipelago clergy] on the insistence of the Porte, excommunicate those bishops who refused to call the people to pay tribute to the Porte and revolt" against the Russians. Materialy dlia istorii Russkogo flota (St. Petersburg: Morskoie ministerstvo, 1888), 12:140. In his struggle for influence with the primus inter pares of the Eastern Orthodox world, Orlov first co-opted the deposed Patriarch Seraphim II and later placed the Archipelago clergy under the jurisdiction of the Spiritual Council, which he established on the island of Paros on the model of the Russian Holy Synod. On Seraphim II, see 
Smilianskaia et. al., Rossia v sredizemnomorie, 183-184. On the Paros Spiritual Council, see Materialy dlia istorii russkogo flota, 12:140-141.

126. "Otvety admirala G. A. Spiridova dukhovenstvu Arkhipelaga o budushchem gosudarstvennom ustroistve," 1771. Smilianskaia et. al., Rossia v sredizemnomorie, 503-10.

127. N. I. Panin to A. G. Orlov, July 21, 1770, Russkii Arkhiv, no. 3 (1880): 230.

128. For these activities see, Smilianskaia et. al., Rossia v sredizemnomorie, 148-161.

129. Ibid., 154-55.

130. See art. 19 of Obreskov's project of peace treaty (Druzhinina, KuchukKainardzhiiskii mir, Prilozhenie 1, 344) that became art. 17 of the peace treaty of Kuchuk Kainarji, Iuzefovich, ed., Dogovory, 34-35.

131. Protocol of the thirty fourth conference of the congress, March 8, 1773, Ulianitskii, Dardanelly, cliv-clv.

132. Ibid.

133. On the establishment of the last four consulates, see the imperial decrees of August 19, 1784 and September 1, 1785, PSZ, ser. 1, nos. 16044 and 16251, vol. 22:196-97 and 447 respectively.

134. See also G. L. Arsh, “O russkoi sisteme “pokrovitel'stva” i o nekotorykh ee sotsial'no-ekonomicheskikh i politicheskikh posledstviakh dlia naselenia Balkan (konets XVIII - nachalo XIX vv.)," Etudes Balkaniques, no. 2 (1975): 108-127.

135. See the instructions to Ivan Voinovich and Ivan Khemnitser, appointed, respectively, the Russian consuls-general in the Archipelago and Smyrna in 1776 and 1782, in V. A. Ulianitskii, Russkie konsul'stva za grantsei v XVIII stoletii. part. 2 (Moscow: Lissner and Gershel, 1899), Prilozhenie 133, dci-dciii; Prilozhenie 127, dlxxi-dlxxiv. 
136. See the standard instruction to the Levantine consuls cited in Ulianitskii, Russkie konsul'stva, part. 1,653-55. Thus, there was no attempt to single out the former "Archduchy" of the Archipelago as a politically more important than any other area of the Levant. The appointment of the Russian consuls and viceconsuls to the Archipelago was an aspect of establishment of a system of Russian consulates in the Levant, which itself was part of the general expansion of the Russian consular network after 1774 advocated by the president of the College of Commerce A. R. Vorontsov. Ibid., 635-53.

137. On the Russian consular protection of Greek trade and the tensions that it caused, see Theophilus C. Prousis, The Russian-Ottoman Relations in the Levant: The Dashkov Archive (Minneapolis, MN: Minnesota Mediterranean and East European Monographs, 2002).

138. Cited in Druzhinina, Kuchuk-Kainardzhiiskii mir, 223.

139. Obreskov to Panin, December 15, 1772, Druzhinina, KuchukKainardzhiiskii mir, Prilozhenie 2, 348.

140. Art. 23 of the Russian project of peace treaty, ibid., Prilozhenie 1, 346, which became 14 of the Kuchuk-Kainardji treaty. Iuzefovich, ed., Dogovory, 31.

141. Art. 24 of the Russian project of peace treaty, Druzhinina, KuchukKainardzhiiskii mir, Prilozhenie 1, 346, corresponding to article 7 of the peace treaty. Iuzefovich, ed., Dogovory, 28-29.

142. Druzhinina, Kuchuk-Kainardzhiiskii, 221.

143. Obreskov to Panin, December 15, 1772, Ibid., Prilozhenie 2, 348.

144. See art. 24 of Obreskov's project of peace treaty, which became art. 7 of the peace treaty. See, respectively, Ibid., Prilozhenie 1, 346 and Iuzefovich (ed.) Dogovory, 28-29.

145. Roderic H. Davison, “'Russian Skill and Turkish Imbecility': The Treaty of Kuchuk-Kajnardji Reconsidered," Slavic Review 35, no. 3 (1976): 463-483, esp. 
$475-76$.

146. As Catherine II in fact called it in her letter to Rumiantsev on April 6, 1774, Petrov (ed.) Voina Rossii s Turtsiei i pol'skimi konfederatami, 5:132.

147. Manifesto of March 17, 1775, PSZ, ser. 1, no. 14274, 20:80-81.

148. Although Davison was right to debunk Albert Sorel's misinterpretation of Kuchuk-Kainarji as the legal foundation of the Russian protectorate over all Russian coreligionists in the Ottoman Empire, one should not ignore the fundamental novelty of the post-1774 situation. The sultan's protection of the Orthodox reaya, hitherto rooted exclusively in the zimmi category of the Muslim law, from now on became transcribed in a treaty with another power. At particular conjunctures, the Russian diplomats would protest in the name of the treaty against what they perceived with greater or lesser justice as the failure of the sultan to exercise his role of protector of the Orthodox community.

149. Catherine II to N. V. Repnin, April 24, 1775, SIRIO, vol. 135, 370.

150. See the memoranda of the Moldavian and Wallachian boyars submitted to Repnin in July and August 1775, SIRIO, vol. 6, 323-31, 344-45.

151. See the 1784 address of the knezes of Raska to Catherine II, in Narochnitskii, Petrović (eds), Politicheskie i kul 'turnye otnoshenia Rossii, 329. On Catherine's relations with the Serbs during this period, see Bazhova, Russko-iugoslavianskie otnoshenia; Vinogradov, ed., Vek Ekateriny II, 197-200. It is remarkable that for more than half a century after 1774, there was not a single Russian consulate in any of the Slavic lands of the Ottoman Empire. See O. V. Medvedeva, “G. V. Vashchenko - pervyi rossiiskii konsul v bolgarskikh zemliakh," in $V$ "interiere” Balakan: Iubileinyi sbornik v chest' Iriny Stepanovny Dostian, ed. I. N. Nikoforov (Moscow: Institut Slavianovedenia RAN, 2010), 244-257.

152. Vinogradov, ed., Vek Ekateriny II, 220-21, 255-56.

153. From the point of view of Russia's relations with the principalities, the 
war of 1787-1791 was to a large extent a repetition of the war of 1768-1774. In 1787, Moldavian clergymen and boyars asked Catherine II "not to deprive them" of "protection and defence." Dragnev, ed., Ocherki, 339-340. In February 1788, the empress responded with a manifesto to the inhabitants of Moldavia and Wallachia, in which she promised the liberation from the "impious yoke of the Hagarians." See Dimitrie A. Sturdza et al, eds., Acte și documente relative la istoria renașterii României (București: Institutul de Arte Grafice Carol Göbl, 1889), 1:217. Once again, the necessity to conclude the war amidst an unfavorable diplomatic situation took the better of this promise and the first Russian version of peace terms with respect to the principalities did not go beyond the confirmation of the existing Russian-Ottoman agreements. See the session of the State Council of December 11, 1788, in Arkhiv gosudarstvennogo soveta, 1:637-38. To mitigate the disappointment of the boyars, Catherine II instructed the vice-chancellor A. A. Bezborodko to demand additional advantages for Moldavia, which according to art. 4 of the Iași peace treaty was to enjoy a two-year tax exemption. See G. S. Grosul, Dunaiskie kniazhezstva v politike Rossii, 1774-1806 (Kishinev: Shtiintsa, 1975), 97-98, and Iuzefovich, ed., Dogovory, 44-45.

154. Norman E. Saul, Russia and the Mediterranean, 1797-1807 (Chicago and London: University of Chicago Press, 1970), 52-69; A. M. Stanislavskaia, Rossia i Gretsia v kontse XVIII - nachale XIX veka. Politika Rossii v Ionicheskoi respublike 1798-1807 (Moscow: Nauka, 1976), 52-89.

155. See Art. 1 of the convention, PSZ, ser. 1, no. 19.336, $26: 89$.

156. See Art. 8 of the convention, Ibid., 91.

157. See Alexander I to (the Russian envoy in Constantinople) A. Ia. Italinskii, October 18, 1804; (Russian foreign minister) Adam Czartoryski to Italinskii, February 27, 1805; Czartoryski to (the Russian plenipotentiary envoy to the Septinsular Republic) G. D. Mocenigo, May 1, 1805; and Cartoryski to Italinskii, May 4, 1805, Vneshniaia politika Rossii XIX i nachala XX veka. ser. 1 (Moscow: Politizdat, 1960-1972), 2:171, 334-35, 408, 413-14. Hereafter cited as VPR.

158. Alexander I to N. N. Novosil'tsev, September 11, 1804, Ibid., 144. See also 
Czartoryski to (the Russian ambassador in London) S. R. Vorontsov, August 18, 1804, Ibid., 121.

159. Alexander I to Italinskii, October 18, 1804, Ibid., 171. Later Czartoryski rearticulated the same idea in Czartoryski to Italinskii, January 3, 1806, VPR, ser. 1, 3:24.

160. See the summary of the Russian draft of the treaty in $V P R$, ser. 1, 2: 678, note 157.

161. The equalization in the legal status of the Christian and Muslim population outlined in the draft of the Russo-Ottoman treaty strikes one as anticipation of the hatt-i sherif of Gulhane of 1839 and the hatt-i humayun of 1856, the two landmark documents of the Ottoman Tanzimat era adopted by the Porte with the British and French encouragement in order to consolidate the loyalty of the Ottoman Christians.

162. Article 6 of the draft treaty obliged the Ottoman government to respect the rights of the Christian population of Venetian Albania that were granted to them by the Russo-Ottoman convention of 1800 . The new treaty contained an explicit reference to Russia's right to make presentations on behalf of these territories before the Ottoman government.

163. See art 9 of the draft treaty cited in $V P R$, ser. 1, 2:678, note 157.

164. Selim I to Alexander I, September 1805, Ibid., 697.

165. See the text of the treaty signed on September 12, 1805 in Ibid., 584-89.

166. Alexander I to Selim III, November 3, 1805, Ibid., 638.

167. Ibid., 638-39.

168. See the messages of the Serbian leaders to (the Russian envoy in Constantinople) A. Ia. Italinskii, May 3, 1804, and to Alexander I, July 15, 1804, I. S. Dostian, ed., Pervoie serbskoie vosstanie. Dokumenty i Materialy (Moscow: 
Nauka 1980), 1:25-30, 36-37.

169. Czartoryski to Italinskii, July 17, 1804, and Czartoryski to Alexander I, not later than November 28, 1804, published in Ibid., 38-41, 65-66.

170. See the address of the Serbian deputies to Czartoryski, November 3, 1804, VPR, ser. 1, 2: 669-70, note 121. In their petitions to Selim III on May 1, 1805 , and November 30, 1805, the Serbs requested self-rule and withdrawal of Ottoman administration from the province. Dostian, ed., Pervoie serbskoie vosstanie, 1:117-20, 183-86.

171. See the messages to Czartoryski to Italinskii of December 4, 1804 and June 4, 1805, Ibid., 76, 135, as well as Alexander I's personal letter to Selim III, April 30, 1806, VPR, ser. 1, 3:143-44.

172. The Russian commander found the Serbs "a nation for which it is shameful to pay tribute to the Porte." I. I. Mikhelson to Karageorge, January 11, 1807, Ibid., 479.

173. The exclusion of the Greeks from the military and civil appointments in Serbia was one of the conditions of its entry under the Russian protection as defined by the protocol of the "conversation" between Karageorge and Alexander I's emissary F. O. Paulucci of June 18, 1807, Dostian, ed., Pervoie serbskoie vosstanie, 1:387.

174. In his conversation with Paulucci, Karageorge invited the Russian Emperor to appoint a civil governor (zemleustroitel') to Serbia, who would bring people to order and introduce a constitution in the name of the Russian emperor and "in accordance with the mores of the people." The Serbian commander did not try to define these mores and only demanded not to distribute land to estate owners (pomeshchiki) and enserf people to them. Ibid. In the absence of a developed discourse of local "rights and privileges," the Russian representative in Serbia K. K. Rodofinikin suggested introducing there Russian laws. See Rodofinikin's memorandum on Serbia addressed to the Russian commander on Danube A. A. Prozorovskii with the latter's comments, November 2, 1808, V. A. Ulianitskii, ed., "Materialy k istorii Vostochnago voprosa v 1808-1813 gg.," ChIODR 199, no. 
4 (1901): vii. Approved by Prozorovskii, this proposal raised expectable doubts in the Russian foreign ministry. See deputy foreign minister A. N. Saltykov to Prozorovskii, December 7, 1808, VPR, ser. 1, 4:426.

175. In their address to Alexander I on July 15, 1804, the Serbian commanders wrote that "unless your imperial majesty spreads his all-beneficent hand [over us], we will perish." In their message to Czartoryski, of November 3, 1804, the Serbian deputies justified their "recourse to the Russian throne" by the fact that the Turks were " rising in arms against the Orthodox faith and preparing its final destruction." In February 1806, the Serbs begged the Russian emperor to "quicken the liberation the Serbian nation and its Orthodoxy" that in the present circumstances will perish forever unless promptly assisted." In June 18, 1806, Karageorge Petrovićh wrote to Alexander I that it depended upon the Russian emperor "to unite for ever with Russia the valiant Serbian people or ruin and loose it forever." Dostian, ed., Pervoie serbskoie vosstanie, 1:37, 61, 218, 257

176. On these divisions, See Lawrence S. Meriage, Russia and the First Serbian Uprising, 1804-1813 (New York: Garland Publishers, 1987).

177. In June 1807, a detachment of 1000 commanded by general Isaev for the first time crossed the Danube and joined the Serbian forces in the siege of Negotin. Three years later a bigger force commanded by generals Zuccato, O'Rourke and Zass joined the Serbs near Pragovo, Kladovo, Deligrad and Bania. Small Russian detachments remained in Serbia for two months after the conclusion of peace in May 1812. A. N. Petrov, Voina s Turtsiei, 1806-1812 gg (St. Petersburg: Voennaia tipografia, 1885-1887), 1:232-236, and 3:162-207, 398-405.

178. Petrov, Voina s Turtsiei, 1806-1812 gg, 1:408. Lashkarev insisted that the truce extends to all the territories in which there were the Russian troops at the moment of negotiations. By contrast, his Ottoman counterpart GhalibEffendi refused to view as Moldavians or Wallachians and considered them as "foes" (supostaty) and "traitors" (izmenniki) not to be included into the truce. The Ottoman representative affirmed the Porte' right to "punish the traitors" and argued that Russian had no right to "interfere into the affairs of internal government of Turkey." See the letters of Lashkarev to Mikhelson, August 1, 
1807, and August 8, 1807, Dostian, ed., Pervoie serbskoie vosstanie, 1:404, 409.

179. I. I. Mikhelson to A. A. Prozorovskii, August 5, 1807, and Prozorovskii's response of August 19, 1807, Russkii arkhiv, no. 7 (1899): 367-368.

180. Prozorovskii to Saltykov, February 9, 1809, Ulianitskii (ed.), "Materialy," xiii-xiv.

181. Prozorovskii's announcement (cited in N. A. Popov, Rossia i Serbia, 18061856 (St. Petersburg: Grachkov i Ko., 1869), 1:73), was approved by Alexander I. See N. P. Rumiantsev (Russian minister of Foreign Affairs in 1808-1813) to Prozorovskii, May 15, 1808, VPR, ser. 1, 4:266.

182. Ieremia Gagić (Karageorge's representative in Bucharest) to (the Russian minister of foreign affairs) A. Budberg, August 16, 1807, Dostian (ed.), Pervoie serbskoie vosstanie, 1:413-14.

183. Prozorovskii to Karageorge, November 29, 1807, Dostian (ed.), Pervoie serbskoie vosstanie. 1:440, repeated in Prozorovskii to the Governing Council of Serbia, March 8, 1808, VPR, ser. 1, 4:199.

184. The Governing Council of Serbia to Prozorovskii, February 20, 1808, Dostian, ed., Pervoie serbskoie vosstanie, 2:15.

185. "A form of government corresponding to the wishes of the people," Rumiantsev to A. A. Prozorovskii, October 4, 1808, VPR, ser. 1,. 4:368; Prozorovskii to Rodofinikin, October 20, 1808, Dostian, ed., Pervoie serbskoie vosstanie, 2:52.

186. Ivan Jugović (Karageorge's representative) to M. I. Kutuzov, February 12, 1809, Ibid., 65.

187. See two Serbian memoranda of March 1, 1809, Ibid., 68-69.

188. Rumiantsev to Prozorovskii, April 10, 1809, Ibid., 75-76, and Prozorovskii to Karageorgii, April 26, 1809, VPR, ser. 1, 5:39-40. 
189. Rumiantsev to P. I. Bagration (who succeeded Prozorovskii as commanderin-chief), January 16, 1810, Dostian, ed., Pervoie serbskoie vosstanie, 2:143-44, and Rumiantsev to N. M. Kamenskii (Bagration's successor as commander-inchief), February 7, 1810, VPR, ser. 1, 5:362.

190. Bagration to Rumiantsev, December 13, 1809, Ibid., 325.

191. Kamenskii to Rumiantsev, December 12, 1810, Dostian, ed., Pervoie serbskoie vosstanie, 2:201.

192. Bagration to Karageorge and the Serbian Governing Council of Serbia, Petrov, Voina Rossii s Turtsiei, 1806-1812 gg., 2:473-77; Kamenskii to the Serbian Governing Council, Karageorge and the entire Serbian people, April 5, $1810, V P R$, ser. 1, 5:421.

193. See art. 7 of the draft peace treaty communicated by Rumiantsev to Kamenskii on February 7, 1810, Ibid., 365, and Kamenskii's modifications to it in Ulianitskii, ed., "Materialy," 66-67.

194. Rumiantsev to Kutuzov, September 30, 1811, VPR, ser. 1, 6:182.

195. M. I. Kutuzov to M. B. Barklai-de-Tolly, October 18, 1811, L. G. Beskrovnyi, ed., M. I. Kutuzov. Sbornik dokumentov (Moscow: Voenizdat, 1952), 3:673; Kutuzov to Rumiantsev, October 15, 1811, VPR, ser. 1, 6:211, agreed by Rumiantsev, October 26, 1811, Ibid., 216.

196. Ibid.

197. Rumiantsev to Kutuzov, March 22, 1812, Ibid., 737, note 362. While the Russians scaled down their demands on behalf of the Serbs, the latter dispatched another delegation to St. Petersburg that restated the desire to remain free from the Porte under Russia's protection. See the letter of the Serbian deputies to Rumiantsev, March 5, 1812, Dostian, ed., Pervoie serbskoie vosstanie, 2:247. Alexander I confirmed his "zealous involvement in the fate of the valiant Serbian people" and promised once again "not to forgo to arrange its lot during the peace negotiations.” Rumiantsev to Karageorgii, April 2, 1812, VPR, ser. 1, 6:356-57. 
198. For his conversation with Italiniski on this subject, on November 19, 1811, see Ibid., 720-21, note 272.

199. See the protocol of December 31, 1811, Ulianitskii, ed., "Materialy," 41-42.

200. Kutuzov to Rumiantsev, April 19, 1812, and the protocol of Ghalibeffendi's conversation with Kutuzov, on April 3, 1812, Beskrovnyi, ed., M. I. Kutuzov, 3:872, 879.

201. See "Osnovnye statii po kotorym dostignuto soglashenie mezhdu glavnokomanduiuschim i pervym turetskim polnomochnym predstavitelem Ghalib-effendi," attached to Kutuzov's instruction to the Russian representatives, May 3, 1812, Ibid., 893.

202. See art. 4 of the preliminary peace conditions of May 5, 1812, Ulianitskii ed., "Materialy," 51-52 and art. 8 of the peace treaty of Bucharest. Iuzefovich (ed.), Dogovory, 54-55.

203. See "Alte trei ponturi adaogite în anaforele către Măria Sa Impărătească și către contele Panin date prin prințul Potemkin,” Iorga, ed., Genealogia Cantacuzinelor, 540.

204. Italinskii to Nesselrode, February 1, 1813, Dostian, ed., Pervoie serbskoie vosstanie, 2:300.

205. Italinskii to Rumiantsev, June 2, 1813, Ulianitskii, ed., "Materialy," 154-60, with an account of his conference with reis-effendi on the Serbian question.

206. For the suppression of the uprising, see Meriage, Russia and the First Serbian Insurrection.

207. Similarly to Catherine II and her diplomats in the early 1770s, Stroganov connected the Russian return of Serbia under the authority of the Porte to the latter's implementation of these conditions. See the protocol of Stroganov's conference with the Porte's foreign minister Halet-Effendi of December 20, 1817, and Stroganov's note to the Porte of December 30, 1817, in $V P R$, ser. 2 , 
(Moscow: Nauka, 1976), 2:760, note 71, and 135-39.

208. See the draft of the convention dated June 20, 1818, in Ibid., 800-803, note 208.

209. Some of Stroganov's letters to the Serbian representative in Bucharest M. F. Gherman and Miloš himself are published in Miroslav Jovanović et als. (eds.) Moskva-Serbia. Belgrad-Rossia. Sbornik dokumentov, vol. 2, Obschestvennopoliticheskie sviazi, 1804-1878 (Belgrade, Moscow: Glavnoie Arkhivnoie Upravlenie goroda Moskvy, 2011), 106-20.

210. Stroganov to Gherman, September 15, 1817, and Stroganov to Miloš, July 21, 1820, Ibid.. 107-108, 109-12.

211. Miloš to Stroganov, June 24, 1820, N. A. Popov, Rossia i Serbia, 1:162.

212. Stroganov to Miloš, April 2, 1820, VPR, ser. 2, 3:346.

213. See Miloš to (the Russian consul-general in Bucharest) A.N. Pini, VPR, ser. 2, 3:757, note 143. Miloš reclaimed the Bucharest treaty in response to the sultan's firman of August 1820 that officially confirmed his appointment as oberknez yet underlined the reaya status of the Serbs. See Miloš to Stroganov, September 3, 1820, Ibid., 784-85, note 231 and N. A. Popov, Rossia i Serbia, $1: 166-67$.

214. Stroganov to Miloš, November 23, 1820, cited in Ibid., 168-169.

215. See art 5 of the convention of Akkerman and the separate act on Serbia, Iuzefovich, ed., Dogovory, 71-72.

216. See art. 6, of the treaty, Ibid., 74-75.

217. See E. Rahić and A. Vtirić, "Vlianie russko-turetskoi voiny 1828-1829 gg. na obretenie nezavisimosti Serbiei," Drinovskyi Zbirnik 5 (2012): 378-387; E. P. Kudriavtseva, Rossia i Serbia v 30-40-kh godakh XIX veka (Moscow: Institut Rossiiskoi Istorii, 2002), 29-30. 
218. Ibid., 69 and further.

219. See the letter of the Patriarch Gregory V (1797-1798, 1806-1808, 1818-1821) to the Greek clergy and people on occasion of the outbreak of the Russian-Ottoman war of 1806-1812, cited in extenso in Sokolov, The Church of Constantinople, 178-180. For similar efforts of patriarchs Procopius I (17851789) and Agathangelos (1826-1830) to secure the loyalty of the Greek millet to the Porte during the wars of 1787-1792 and 1828-1829, see Ibid., 128-29 and 290-92 respectively.

220. Orlando Figes, The Crimean War: A History (New York: Metropolitan Books, 2010), 9.

221. See, in particular, Victor Taki, "Moldavia and Wallachia in the Eyes of the Russian Observers in the First Half of the Nineteenth Century," East-Central Europe/L'Europe du Centre-Est 32, nos. 1-2 (2005): 199-224. 


\section{References}

Aksan, Virginia H. Ottoman Wars, 1700-1870: An Empire Besieged. Harlow, UK: Pearson, 2007.

Ardeleanu, G. S. "Știri din correspondența lui Petru I," Studii și cercetări de istorie medie, no. 1 (1950): 192-208.

Arkhiv gosudarstvennogo soveta. 5 vols. St. Petersburg: Tipografia Vtorogo Otdelenia Sobstvennoi E. I. V. Kantseliarii, 1869-1904.

Arsh, L. G. "Rossiiskie emissary v Peloponese i Arkhipelagaskaia ekspeditisa 1770-1774." Novaia i noveishaia istoria, no. 6 (2010): 60-72.

. "O russkoi sisteme "pokrovitel'stva" i o nekotorykh ee sotsial'noekonomicheskikh i politicheskikh posledstviakh dlia naselenia Balkan (konets XVIII - nachalo XIX vv.).” Etudes Balkaniques, no. 2 (1975): 108-127.

Bazhova, A. P. Russko-iugoslavianskie otnoshenia vo vtoroi polovine XVIII v. Moscow: Nauka, 1982.

Beskrovnyi, L. G., ed. M. I. Kutuzov. Sbornik dokumentov. Moscow: Voenizdat, 1950-1956.

Camariano-Cioran, Ariadna. "La Guerre Russo-turque de 1768-1774 et le Grecs.” Revue des Etudes Est-Européenes 3, nos. 3-4 (1965): 513-547.

Cantemir, Dmitrie. The History of the Growth and Decay of the Othman Empire. Transl. N. Tindal, 2 vols. London: James, John, and Paul Knapton, 1734-35.

Cazacu, Mihai. "Familles de la noblesse roumaine au service de la Russie, XVe - XIXe siècle.” Cahiers du monde russe et soviétique 34, nos. 1-2 (1993):211-226.

Colson, Felix. De l'Etat présent et de l'avenir de principautés de Moldavie et de Valachie. Paris: A. Pougin, 1839. 
Constantiniu, Florin and Șerban Papacostea. "Les réformes des premiers princes phanariotes en Moldavie et en Valachie: Essai d'interpretation." Balkan Studies 13, no. 1 (1972):ß 89-118.

Davis, Brian L. Empire and Military Revolution in Eastern Europe: Russia's Turkish Wars of the Eighteenth Century. London; New York: Continuum, 2011.

Davison, Roderic H. "'Russian Skill and Turkish Imbecility': The Treaty of Kuchuk-Kajnardji Reconsidered." Slavic Review 35, no. 3 (1976): 463-483.

Documente privitoare la Istoria Românilor. 21 vols. București: Editura Socecu, 1887-1942.

Dostian, I. S., ed. Pervoie serbskoie vosstanie. Dokumenty i materialy. 2 vols. Moscow: Nauka 1980-1983.

Dragnev, D. M., ed. Ocherki vneshnepoliticheskoi istorii moldavskogo kniazhestva (posledniia tret'XIV-nachalo XIX v. Kishinev: Shtiintsa, 1987.

Dragomir, Silviu. Contribuții privitoare la relațiile biserici românești cu Rusia în veacul XVII. București: Șosec C. Sfetea. Librărie Națională, 1912.

Druzhinina, E. I. Kuchuk-Kainardzhiiskii mir1774 goda. Moscow: Akademia Nauk SSSR, 1955.

Dvoichenko-Markov, D. "Russia and the First Accredited Diplomat in the Danubian Principalities." Slavic and East European Studies 8 (1963): 200-229.

Focșeneanu, Ion. "Tratatul de la Luțk și Campania Țarului Petru I în Moldova (1711).” In Studii privind relațiile romîno-ruse, 1-55. București: Academia Republicii Populare Romîne, 1963.

Eremia, Ion. “Considerații privid tratatul moldo-rus de la 1711.” In Frontierile Spațiului Românesc în Contextul European ,edited by Sorin Șipoș, Mircea Brie, Florin Șprengeu and Ion Gumenâi, 102-120. Chișinau: Editura Cartdidact, 2008. 
Figes, Orlando. The Crimean War: A History. New York: Metropolitan Books, 2010 .

Fortunatov P. K., ed. P. A. Rumiantsev. Sbornik dokumenov i materialov. 3 vols. Moscow: Voiennoie izdatel'stvo ministerstva oborny SSSR, 1953-59.

Freidenberg, M. M. "Stepan Malyi iz Chernogorii," Voprosy istorii, no. 10 (1975): 118-132.

Gemil, Tahsin. Relațiile Țărilor române cu Poarta otomană în documente turcești (1601-1712). București: Direcția Generala a Arhivelor Statului din Republica Socialistă România. 1984.

Romanian Academy, 2009.

. Romanians and Ottomans in the XIVth to XVIth Centuries. Bucharest: . Țările române în contextul politic internațional (1621-1672). București: Editura Academiei Republici Socialiste România, 1979.

Georgescu, Vlad ed. Mémoires et projets de reformes dans les principautés Roumaines, 1769-1830. Bucarest: Association internationale d'études du Sud-Est Européen, 1970.

Girs, A. A. "Iz proshlogo konsul'stva v Iassakh," Russkaia starina 89 (1897):315-25.

Giurescu, Constantin. Capitulațiile Moldovei cu Poarta Ottomană. București: Institutul de Arte Grafice Carol Göbl, 1908.

Görtz, Johann Eustachius, ed. Mémoires et actes relatives aux négociations qui ont précédé le partage de la Pologne. Paris: s. n., 1810.

Grosul, G. S. Dunaiskie kniazhestva v politike Rossii, 1774-1806. Chişinău: Shtiintsa, 1975.

Grosul, V. Ia. Reformy v Dunaiskikh kniazhestvakh 20-kh-30-kh gg. XIX veka i Rossia. Moscow: Nauka, 1966. 
Hurewitz, J. C., ed. The Middle East and North Africa in World Politics: A Documentary Record. 3 vols. New Haven and London: Yale University Press, 1975.

Inalcik, Halil, with Donald Quataert, eds. An Economic and Social History of the Ottoman Empire. 2 vols. Cambridge, UK: Cambridge University Press, 1997.

Ionescu, Dimitrie G. "Tratatul lui Gheorghe Stefan cu rușii," Revista istorică romînă 3, nos. 2-3 (1933): 241-46.

Iorga, Nicolae. Byzance après Byzance. Bucarest: L'Institut d'Etudes Byzantines, 1935.

., ed. Genealogia Cantacuzinelor de banul Mihai Cantacuzino. București: Institutul de Arte grafice și Editură Minerva, 1902.

Istoricheskie sviazi narodov SSSR i Rumynii. 3 vols. Moscow: Nauka, 19651970.

Iuzefovich, T. P., ed. Dogovory Rossii s Vostokom. St. Petersburg: tip. O. I. Baksta, 1869.

Jewsbury, George F. Russian Annexation of Bessarbia, 1774-1828: A Study of Imperial Expansion. Boulder, Colo.: East European Monographs, 1975.

Jovanović, Miroslav eds Moskva - Serbia. Belgrad - Rossia. Sbornik dokumentov. vol. 2. Obschestvenno-politicheskie sviazi, 1804-1878. Moscow, Belgrade: Glavnoie Arkhivnoie Upravlenie goroda Moskvy, 2011.

Khitrova, N. I. "Russko-chernogorskie sviazi v XVIII v. (tserkovnye i kul'turnye)." In XVIII vek: Slavianskie i Balkanskie narody i Rossia, edited by I. I. Leshchilovskaia, 6-26. Moscow: Institut slavianovedenia i balkanistiki RAN, 1998, 6-26.

Kogălniceanu, Mihai. L'Istoire de la Dacie, des Valaques Trasdanubiennes et de la Valachie. Berlin: Librairie B. Behr, 1854. 
Kudriavtseva, E. P. Rossia i Serbia v 30-40-kh godakh XIX veka. Moscow: Institut Rossiiskoi Istorii, 2002.

Martens, Georg Friedrich von. ed. Recueil des principaux traites d'alliance. 7 vols. Gottingen: Jean Chrétien Dietrich, 1791-1801.

Maslovskii, D. F. Stavuchanskii pokhod. Dokumenty 1739 g. St. Petersburg: Voenno-uchebnyi komitet Glavnogo Shtaba, 1892.

Materialy dlia istorii Russkogo flota. 17 vols. St. Petersburg: tip. Morskogo ministerstva, 1865-1904.

Maxim, Mihai. Țările Române ți Înaltă Poarta. București Editura Enciclopedica, 1993.

Medvedeva, O. V. "G. V. Vashchenko - pervyi rossiiskii konsul v bolgarskikh zemliakh." In $V$ "interiere” Balakan: Iubileinyi sbornik v chest' Iriny Stepanovny Dostian, edited by I. K. Nikiforov, 244-57. Moscow: Institut Slavianovedenia RAN, 2010.

Meriage, Lawrence S. Russia and the First Serbian Uprising, 1804-1813. New York: Garland Publishers, 1987.

Mischevca, Vladimir and Periklis Zavitsanos, Principele Constantin Ypsilanti. Chişinău: Civitas, 1999.

Mitilineu, Mihai, ed. Colecțiune de tratatele și convențiunile ale României cu puterile straine. București: Noua tipografia ale laboratorilor români, 1874.

Narochnitskii, A. L., and N. Petrovic, eds. Politicheskie i kul'turnye otnoshenia Rossii s iugoslavianskimi zemliami v XVIII v. Dokumenty. Moscow: Nauka, 1984.

Nouradounghian, Gabriel Effendi, ed. Recueil d'actes internationaux de l'Empire Ottoman. 4 vols. Paris: Librairie Cotillon, 1897-1903.

Panaite, Viorel. Pace, Război și Comerț în Islam. Țările Romăne și Dreptul Otoman al Popoarelor (secolele XV-XVII). București: B.I.C. ALL, 1997. 
. "The Re' ayas of the Tributary Protected Principalities: The Sixteenth Through the Eighteenth Centuries." International Journal of Turkish Studies 9, nos. 1-2 (2003): 79-104.

. "The voivodes of the Danubian principalities — as harâcgüzarlar of the Ottoman Empire," International Journal of Turkish Studies 9, nos. 1-2 (2003), 59-78.

Papacostea, Şerban. Oltenia sub stapânirea austriaca, 1718-1739. București: Editura Enciclopedică, 1998.

Petrov, A. N. Voina Rossii s Turtsiei i pol'skimi konfederatami, 1768-1774. 5 vols. St. Petersburg: tip. Eduarda Veimera, A. Transhelia, K. V. Trubnikova i V. A. Poletika 1866-1874. tipografia, 1885-87.

Voina s Turtsiei, 1806-1812 gg. 3 vols. St. Petersburg: Voennaia

Philliou, Christine M. Biography of an Empire: Governing the Ottomans in an Age of Revolution. Berkley, CA: University of California Press, 2011.

Pocock, J. G. A. Politics, Language and Time: Essays on Political Thought and History. New York: Atheneum, 1971.

Polnoie sobranie zakonov Rossiiskoi Imperii, ser. 1, vols. 2, 4, 18, 19, 20, 22 , 26; ser. 2, vol. 3. St. Petersburg: Tipografia Vrotogo Otdeleinia Sobstvennoi E. I. Velichestva Kantseliarii, 1830.

Popov, N. A. Rossia i Serbia, 1806-1856. 2 vols. St. Petersburg: Grachkov i Ko., 1869-1871.

Prousis, Theophilus C. The Russian-Ottoman Relations in the Levant: The Dashkov Archive. Minneapolis: University of Minnesota, 2002.

Rahić, E., and A. Vtirić, "Vlianie russko-turetskoi voiny 1828-1829 gg. na obretenie nezavisimosti Serbiei," Drinovskyi Zbirnik 5 (2012): 378-387. 
Richter, Melvin. "Reconstructing the History of Political Languages: Skinner, Pocock and Geschichtliche Grundbegriffe," History and Theory 29, no. 1 (1990): 38-70.

Saul, Norman E. Russia and the Mediterranean, 1797-1807 (Chicago and London: University of Chicago Press, 1970.

Sbornik Imperatrskogo Russkogo Istoricheskogo Obshchestva, vols. 1, 2, 6, 12, 19, 97, 135. St. Petersburg: Imperatorskaia Akademia Nauk, 1867-1912.

Semenova, L. E. Kniazhestva Moldavia i Valakhia, konets XIV-nachalo XIX vv. Ocherki vneshnepoliticheskoi istorii. Moscow: Indrik, 2006.

Shul'man, E. B. "Prorusskaia partia v Valakhii i ee sviazi s Rossiei. 1736-1737." In Russko-rumynskie i rumynsko-russkie otnoshenia. Kishinev: Shtiintsa, 1969, $7-41$.

gg.)." In Vekovaia druzhba, 211-39 Kishinev: Shtiintsa, 1963.

Skinner, Barbara. The Western Front of the Eastern Church: Uniate and Orthodox Conflict in $18^{\text {th }}$ Century Poland, Ukraine, Belarus and Russia. DeKalb, IL: Northern Illinois University Press, 2011.

Smilianskaia, E. B., I. M. Smilianskiaia, and M. B. Velizhev, Rossia v Sredizemnomorie: Arkhipelagskaia ekspeditsia Ekateriny II. Moscow: Indrik, 2006.

Sokolov, Ivan. The Church of Constantinople in the Nineteenth century. An Essay in Historical Research. Translated from the Russian by Hieromonk Nikolai Sakharov. Oxford: Peter Lang, 2013.

Spiridonakis, B. G. "Le Consulat Russe dans les principautés Danubiennes." Balkan Studies 4 (1963): 289-314.

Stanislavskaia, A. M. Rossia i Gretsia v kontse XVIII - nachale XIX veka. Politika Rossii v Ionicheskoi respublike 1798-1807. Moscow: Nauka, 1976. 
Storia della Guerra presenta tra la Russia, la Polonia e la Porta Ottomana. 5 vols. Venice: Graziosi, 1770.

Sturdza Dimitrie A., C. Colescu-Vartic, G. Petrescu, D. C. Sturdza and J. J. Skupiewski eds. Acte și documente relative la istoria renașterii României. 10 vols. București: Carl Göbl, 1889-1909.

Sumner, H. B. Peter the Great and the Ottoman Empire. Oxford, UK: Basil Blackwell, 1949.

Ulianitskii, V. A. Dardanelly, Bosfor i Chernoie more v XVIII v. Moscow: A. Gatsuk, 1883.

. ed. "Materialy k istorii Vostochnago voprosa v 1808-1813 gg.," Chtenia v Imperatorskom Obshchestve Istorii i Drevnostei Rossiiskikh 199, no. 4 (1901), i-xvi + 1-196.

. Russkie konsul'stva za grantsei v XVIII stoletii. Moscow: Lissner and Gershel, 1899.

Taki, Victor. "Moldavia and Wallachia in the Eyes of the Russian Observers in the First Half of the Nineteenth Century," East-Central Europe/L'Europe du Centre-Est 32, nos. 1-2 (2005): 199-224.

Taki, Victor. "Russia on the Danube: Imperial Expansion and Political Reform in Moldavia and Wallachia, 1812-1834." PhD. Thesis, Central European University, 2007.

Tully, James, ed. Meaning and Context: Quentin Skinner and His Critics. Princeton, NY: Princeton University Press, 1988.

Vianu, A. "Cîteva date privitoare la emigrarea romînilor în sudul Rusiei în secolul al XVIII-lea," Studii privind relațiile romîno-ruse, 57-65. București: Academia Republicii Populare Romîne, 1963.

Vinogradov, V. N., ed. Bessarabia na perekrestke evropeiskoi diplomatii. Moscow: Indrik, 1996. 
. ed. Vek Ekateriny II. Dela Balkanskie. Moscow: Nauka, 2000.

Vinogradov, V. N., L. E. Semenova, "Nekotorye voprosy otnoshenii mezhdu Rossiiei i Dunaiskimi kniazhestvami v XVIII - nachale XIX veka vsvete materialov sovetskikh arkhivov." In Balkanskie narody i evropeiskie pravitel 'stva, edited by G. L. Arsh, 6-37. Moscow: Nauka, 1982.

Vneshniaia politika Rossii XIX i nachala XX veka. ser. 1, vols. 2-6 and ser. 2, vols. 2-3. Moscow: Politizdat, Nauka, 1963-1979.

Xenopol, A. D. Epoca Fanarioţilor pâna la 1812. Iaşi: Editura librăriei şcoalelor Fraţii Saraga, 1896. 